\title{
A NEW SHORT-SNOUTED RHINESUCHID FROM THE PERMIAN OF SOUTHERN BRAZIL
}

\author{
ELISEU VIEIRA DIAS (1) \\ Centro de Ciências Biológicas e da Saúde, Universidade Estadual do Oeste do Paraná, \\ Rua Universitária, 2069, 85819-110, Cascavel, PR, Brazil. \\ eliseu.dias@unioeste.br / eliseuvdias@gmail.com \\ SÉRGIO DIAS-DA-SILVA (1) \\ Departamento de Ecologia e Evolução, Universidade Federal de Santa Maria, \\ Av. Roraima, 1000, Prédio 17, Sala 1140-I, 97105-900, Santa Maria, RS, Brazil. \\ paleosp@gmail.com \\ CESAR LEANDRO SCHULTZ (1) \\ Instituto de Geociências, Departamento de Paleontologia e Estratigrafia, UFRGS, \\ Av. Bento Gonçalves, 9500, 91509-900. Porto Alegre, RS, Brazil. \\ cesar.schultz@ufrgs.br
}

\begin{abstract}
A new basal stereospondyl taxon from the Permian is described. The material used to erect the new taxon consists of a series of mandibles and some postcranial elements. A single badly preserved short-snouted skull is considered as referred material. Rastosuchus hammeri gen. et sp. nov. presents conical teeth along all coronoid bones, the prearticular extending anteriorly at the level of the precoronoid and enlarged anterior meckelian foramina. Based on the referred material, R. hammeri gen. et sp. nov. also presents posterior premaxillary teeth larger than anterior ones, the cultriform process of the parasphenoid compressed laterally forming a medial ventral keel, posterolateral ramus of the vomer extends posterior to the palatine tusks, and rounded orbit with flat orbital bones at the same level of the skull roof, features shared with Australerpeton cosgriffi and other rhinesuchids. Australerpeton cosgriffi and Rastosuchus hammeri gen. et sp. nov. are from the upper layers of the Rio do Rasto Formation (Paraná Basin) in the Paraná State, southern Brazil, and its deposition in freshwater continental environments is reinforced by the presence of temnospodyls amphibians.
\end{abstract}

Keywords: Rhinesuchidae, Temnospondyli, Rastosuchus, Guadalupian-Lopingian, Rio do Rasto Formation.

RESUMO - Um novo táxon de estereospôndilo basal brasileiro é descrito para o Permiano. O material utilizado para propor o novo táxon consiste em uma série de mandíbulas e alguns elementos pós-cranianos. Um único crânio mal preservado, de rostro curto, é considerado como material referido. Rastosuchus hammeri gen. et sp. nov. apresenta dentes cônicos ao longo de todos os ossos coronoides, pré-articular se estendendo anteriormente até o nível do pré-coronoide e amplos foramens meckelianos anteriores. Baseado no material referido, $R$. hammeri gen. et sp. nov. também apresenta dentes pré-maxilares posteriores maiores que os anteriores, o processo cultriforme do paraesfenoide comprimido lateralmente formando um quilha ventral medial, ramo posterolateral do vômer estendendo-se posteriormente às presas do palatino, e órbita arredondada com ossos orbitais achatados e no mesmo nível do teto do crânio, características compartilhadas com Australerpeton cosgriffi e outros rinessuquídeos. Australerpeton cosgriffi e Rastosuchus hammeri gen. et sp. nov. são provenientes das camadas superiores da Formação Rio do Rasto (Bacia do Paraná) no Estado do Paraná, sul do Brasil, e a presença de anfíbios temnospôndilos reforça a interpretação de que esta foi depositada em ambientes continentais dulciaquícolas.

Palavras-chave: Rhinesuchidae, Temnospondyli, Rastosuchus, Guadalupiano-Lopingiano, Formação Rio do Rasto.

\section{INTRODUCTION}

The temnospondyls are a large group of amphibians represented in the fossil record from the Carboniferous to Lower Cretaceous (Milner \& Sequeira, 1994). Rhinesuchids were medium to large-sized mostly semi-aquatic temnospondyls that ranged from Cisuralian (Permian) to Early Triassic of southern Africa, Brazil, India and Madagascar (Schoch \& Milner, 2000, Damiani, 2004, Cisneros et al., 2015, Marsicano et al., 2017). The family Rhinesuchidae was erected by Watson (1919), and during a century they were a neglected temnospondyl group (Schoch \& Milner, 2000; Pawley \& Warren, 2004). 
Damiani \& Rubidge (2003) included the Rhinesuchidae on its review of the South African temnospondyls, however, they called attention to the provisional status of all remarks they presented. After Marsicano et al. (2017) this situation seems to have changed and several South African specimens could be properly studied.

Schoch \& Milner (2000) reviewed the content of Rhinesuchidae, and as a result, several taxa based on fragmentary material had their taxonomic status reconsidered and synonymized to better known rhinesuchids, such as Uranocentrodon, Rhineceps and Rhinesuchus. However, these authors did not test the taxonomic status of Rhinesuchidae under a phylogenetic approach.

Two comprehensive taxonomic reviews of temnospondyls under a phylogenetic approach (Yates \& Warren, 2000; Damiani, 2001) found rhinesuchids as basal stereospondyls close related to Capitosauria (Mastodonsauroidea sensu Damiani, 2001). Unfortunately, Yates \& Warren (2000) used Rhinesuchidae as a terminal taxon through the artificial construction of a chimaera representing all rhinesuchids (they used the sincranium of Rhineceps and the postcranial skeleton of Uranocentrodon). Conversely, Damiani (2001), in his phylogenetic analysis of mastodonsauroids, included three better known rhinesuchids as outgroup taxa in his datamatrix (Rhineceps, Rhinesuchus and Uranocentrodon). As a result, they formed a monophyletic group closely related to 'lydekkerinids' and Mastodonsauroidea. However, as the taxonomic status of Rhinesuchidae was not the aim of his work, Damiani (2001) did not provide any discussion regarding this issue.

Eltink et al. (2016) reviewed in details the Australerpeton cosgriffi cranial morphology and discussed the phylogenetic status of the Rhinesuchidae. Their most parsimonious tree recovered the Rhinesuchidae as a monophyletic group due to some features of the tympanic cavity and divided into Rhinesuchinae and Uranocentrodon+Australerpetinae. Marsicano et al. (2017) reviewed the African and South American rhinesuchids, recognizing seven genera with eight valid species, and performed a phylogenetic analysis that supports the monophyly of Rhinesuchidae with Australerpeton as sister-taxon to all other rhinesuchids also considering the tympanic region as important for the group. Eltink et al. (2019) also recovered the monophyly of the Rhinesuchidae, adding other features to the list of synapomorphies and dividing them into Rhinesuchinae and Australerpetinae.

Brazilian rhinesuchids, as well as other Paleozoic temnospondyls, come from the Parnaiba and Paraná sedimentary basins. In northeastern Brazil occurs the archegosaurid Prionosuchus plummeri described by Price (1948) that was revised by Cox \& Hutchinson (1991), and recently Cisneros et al. (2015) described the Trimerorhachidae Procuhy nazariensis, the Dvinosauria Timonya anneae, and presented an indeterminate Rhinesuchidae, all of them from the Pedra de Fogo Formation, Parnaiba Basin. In southern Brazil, Paleozoic temnospondyls are more common in the
Rio do Rasto Formation of the Paraná Basin, and only three occurrences represent non-rhinesuchid taxa: the probable Archegosauridae Bageherpeton longignathus Dias \& Barberena, 2001, the Stereospondylomorpha Parapytanga catarinensis Strapasson et al., 2015, and the Konzhukoviidae Konzhukovia sangabrielensis Pacheco et al., 2016. On the other hand, the majority of the occurrences are somehow related to the rhinesuchids. One of them is the long-snouted Australerpeton cosgriffi described by Barberena (1998) based on cranial materials, later complemented with studies on its squamation (Dias \& Richter, 2002), postcranium (Dias \& Schultz, 2003a), paleobiology (Dias \& Schultz, 2003b), and proposals of reconstruction (Langer et al., 2008; Eltink \& Dias, 2012). New specimens of $A$. cosgriffi were also reported by Sedor \& Costa (2001), Eltink \& Langer (2008, 2014), Ramos \& Vega (2011), Eltink et al. (2016) and Azevedo et al. (2017). All known specimens of the long-snouted $A$. cosgriffi are from several outcrops on the Serra do Cadeado area and an outcrop nearby São Jerônimo da Serra, both areas on the Paraná State. Finally, a short-snouted amphibian, also collected at the Serra do Cadeado area, was previously mentioned by Barberena $e t$ al. $(1980 ; 1985 \mathrm{a}, \mathrm{b})$ and preliminarily described by Barberena $\&$ Dias (1998) as a rhinesuchoid. These last occurrences are presented here as a new taxon of rhinesuchid temnospondyl.

The discovery of another short-snouted temnospondyl skull from the Rio do Rasto Formation, collected in the São Jerônimo da Serra site, was noticed by Souza \& Vega (2011). The specimen is housed in the Departamento de Geologia/ Universidade Federal do Paraná (UFPR-0150-PV), but it has not been formally described yet, and the taxonomic assignment of this material is beyond the scope of this article.

\section{GEOLOGICAL SETTING}

The Paraná Basin is an extensive intracratonic site of sedimentation filled with marine and continental rocks from Ordovician to Cretaceous. It is situated in South America, extending over part of Brazil, Paraguay, Argentina and Uruguay, comprising about 1.7 million $\mathrm{km}^{2}$ (Milani et al., 1998, 2007; Schultz et al., 2000; Holz et al., 2010). The middle to upper Permian strata of the Paraná Basin represents a regressive progradational sequence (Milani et al., 1998) at the top of which is the Rio do Rasto Formation. This unit is mainly interpreted as a wide lacustrine system (Ragonha, 1989) with the association of fluvial and deltaic facies, and peripheral aeolian dunes representing a separated unit known as Pirambóia Formation (Lavina et al., 1993). The "Pirambóia dune fields" could represent lateral and vertical facies variation of the "Rio do Rasto lacustrine system", and be considered Permian (Lavina \& Scherer, 2003) at least on its lower levels. The Rio do Rasto and Pirambóia formations represent the final stage of a great regressive cycle in the Paraná Basin (Milani et al., 1998; 2007).

The Rio do Rasto Formation is subdivided into the lower Serrinha and the upper Morro Pelado members. 
The Serrinha Member is mostly composed of greenish to purplish sandstones, siltstones and mudstones (Schneider et al., 1974), comprising a scenario of wide lakes with rivers and deltas on their borders (Holz et al., 2010). A study on carbonate concretions confirms that Serrinha Member deposition system was a large and shallow freshwater body without connection to Panthalassa Ocean (Alessandretti et al., 2015). The Morro Pelado Member is mainly composed of reddish fine sandstones and mudstones (Schneider et al., 1974), comprising a scenario of river deltas and smaller lakes, and due to the presence of intermeshed aeolian dunes, it was deposited under an aridization trend (Rohn et al., 1997). This trend toward drier conditions is attested by the presence of several mudcrack levels and dipnoan aestivation burrows (Francischini et al., 2018).

The Serra do Cadeado area comprises a Permian to Cretaceous sequence of rocks with an important exposed record of the upper Permian Rio do Rasto Formation (Barberena et al., 1980; Langer et al., 2008). The area is between Ortigueira and Mauá da Serra, small towns that are respectively at the base and the top of the regional escarpment (Figure 1). One highway and a railway cross the area providing several outcrops where the majority of the fossils were found. For an overview on the geological and paleontological importance of the Serra do Cadeado region see Langer et al. (2008).

\section{FOSSILIFEROUS CONTENT AND BIOSTRATIGRAPHY}

The vertebrate fossil record of the Morro Pelado Member include fishes, temnospondyls, pareiasaurs, anomodonts, dicynodonts, dinocephalians and vertebrate ichnofossils (e.g. Barberena \& Araújo, 1975; Araújo, 1984; Ragonha, 1989; Barberena, 1998; Barberena \& Dias, 1998; Richter \& Langer, 1998; Langer, 2000; Vega-Dias et al., 2000; Dias \& Barberena, 2001; Leonardi et al., 2002; Malabarba et al., 2003; Laurini et al., 2009; Cisneros et al., 2005, 2011, 2012; Dias, 2012; Silva et al., 2012; Pauliv et al., 2012, 2014; Strapasson et al., 2015; Boss et al., 2016; Pacheco et al., 2016; Francischini et al., 2018).

In the earliest biostratigraphic frameworks of the Rio do Rasto Formation, the temnospondyls found in the Serra do Cadeado area (Australerpeton cosgriffi and Rastosuchus hammeri, name only), as well as other tetrapods, allowed the correlation to the South African Cistecephalus Zone (Barberena et al., 1980, 1985a,b, 1991). Later, Langer (2000), Langer \& Lavina (2000), Cisneros et al. (2005) and Langer et al. (2008) provided upgraded interpretations regarding the vertebrate content and biostratigraphy of the Rio do Rasto Formation. These publications were based upon the discovery of new fossil material and collection revisions. According to Cisneros et al. (2005), the Serra do Cadeado fauna would be

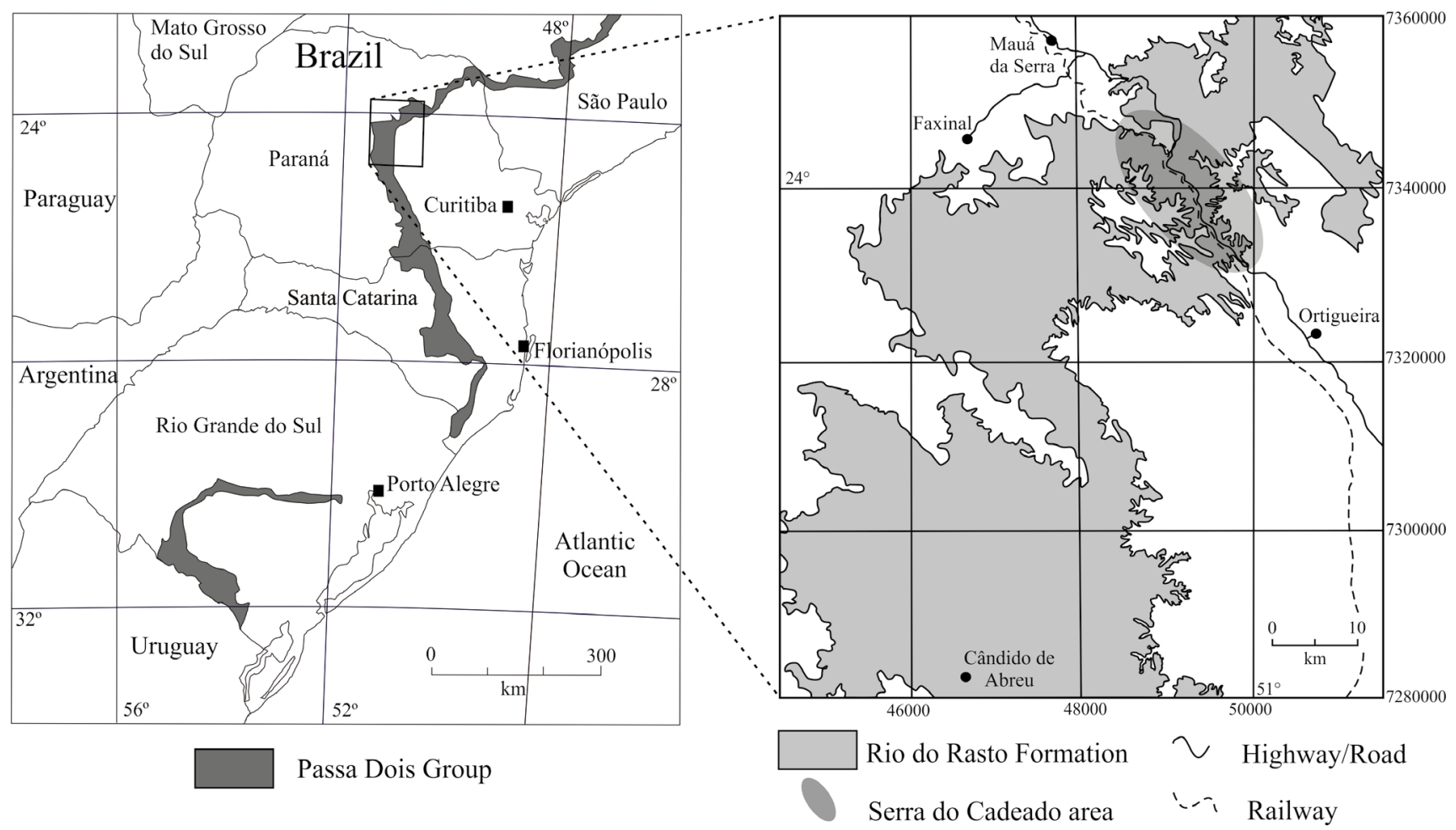

Figure 1. Simplified maps placing the outcrop area of the Passa Dois Group that includes the Rio do Rasto Formation with indication of the Serra do Cadeado region in the State of Paraná, southern Brazil. 
correlated to the upper portion of the Pristerognathus, the entire Tropidostoma, and the base of the Cistecephalus zones. Dias-da-Silva (2011) revised these previous biostratigraphic works and based on new findings proposed that Serra do Cadeado local fauna extends from somewhat below the Eodicynodon to the top of Cistecephalus Assemblage Zones, which includes also the Tapinocephalus, Pristerognathus and Tropidostoma Assemblage Zones.

Paleobotanical data (Rohn, 1994; Rohn \& Rosler, 2000) and biostratigraphy based on vertebrates (Langer, 2000; Malabarba et al., 2003, Cisneros et al., 2005) suggests a Guadalupian to Lopingian age for the Rio do Rasto Formation. According to Holz et al. (2010) the age of the Serrinha Member is middle Permian (Guadalupian) from Wordian to Capitanian, while the Morro Pelado Member is mostly late Permian (Lopingian) from Wuchiapingian to Changhsingian. Alessandretti et al. (2016) presented a U-Pb detrital zircon dating with minimal ages of 273-275 Ma for the Serrinha Member, placing it close to the Kungurian-Rodian limit, and $261 \mathrm{Ma}$ for the Morro Pelado Member placing it in the Capitanian, comprising almost the entire Guadalupian, while Canile et al. (2016) found a zircon of $252 \mathrm{Ma}$ in the Morro Pelado Member, which is Lopingian according to ICS (2019). Once there is not a consensus, any of these ages was assumed.

Leonardi et al. (2002) reported the discovery of ichnofossils of the ichnogenus Rhynchosauroides (Lepidosauria) and Dicynodontipus (Cynodontia) in the Morro Pelado Member of the northern Paraná State, and these ichnofossils were formally described by Silva et al. (2012). Dentzien-Dias et al. (2012) describes a coprolite rich site for southernmost Brazil and Rochinski \& Dias (2015) noticed a similar occurrence. Studies on coprolites lead the discovery of tapeworm eggs (Dentzien-Dias et al., 2013) and fossil actinomycete fungi remains (Dentzien-Dias et al., 2017). Francischini et al. (2018) presents an ichnofossil attributed to dipnoan aestivation. Vertebrate ichnofossil occurrences points to the existence of a yet hidden biodiversity for the Rio do Rasto Formation as already suggest by Silva et al. (2012). New findings and taxon descriptions can shed some light on this matter.

\section{MATERIAL AND METHODS}

The specimens here presented were collected by Dr. Mario C. Barberena $\uparrow$ and his colleagues during the 1970s and 1980s fieldtrips to the Rio do Rasto Formation at the Serra do Cadeado area in the Paraná State, Brazil (Figure 1). The fossils are deposited in the collection of the Laboratório de Paleontologia de Vertebrados of the Universidade Federal do Rio Grande do Sul under the code UFRGS-PV.

The material here assigned to Rastosuchus hammeri gen. et sp. nov. comprises almost complete and fragments of mandibular rami (UFRGS-PV-0235-P, UFRGS-PV0349-P, UFRGS-PV-0350-P, UFRGS-PV-0357-P), and some postcranial elements (UFRGS-PV-0356-P). In addition, the specimen UFRGS-PV0352-P, a partial skull with the left mandibular ramus almost complete and a right ramus fragment both strongly attached to the skull, is here referred to $R$. hammeri gen. et sp. nov.

Two of the isolated mandibular rami are almost complete: UFRGS-PV-0349-P is a left ramus lacking only the postglenoid area, and UFRGS-PV-0350a-P is a right ramus lacking only the symphysial area. The other mandibular rami are more incomplete: UFRGS-PV-0350b-P is a left ramus posterior half with a well-preserved postglenoid area; UFRGS-PV-0235-P is an anterior segment with a wellpreserved symphysial area; UFRGS-PV-0357-P lacks both the symphysial area and the posterior area of the adductor fossa. This set of mandibular samples shares the same diagnostic features providing information to reconstruct a composite complete mandible. The postcranial material deposited as UFRGS-PV-0356-P includes a well-preserved left clavicle, cleithrum, scapulocoracoid, hind limb, few isolated vertebral elements, and some fragmentary ribs.

According to Dr. Mario C. Barberena $\dagger$ (personal communication), the mandible UFRGS-PV-0357-P was collected exactly at the same place of the postcranial elements numbered as UFRGS-PV-0356-P, suggesting that both would belong to the same individual. However, they received distinct sequential numbers because UFRGS-PV0356-P was collected during the expeditions of the late 1970s while UFRGS-PV0357-P was found in other expedition of the earliest 1980s when the same collection site was revisited. The level where UFRGS-PV0356-P and UFRGS-PV-0357-P were found is positioned in the lower portion of the Morro Pelado Member nearby the transition to the underlying Serrinha Member. Slightly above that level, UFRGS-PV-0235-P, UFRGS-PV0350-P UFRGS-PV-0352-P came roughly from a single stratigraphic level just above the first site. Otherwise, the specimen UFRGS-PV-0349-P was collected in upper levels of the Morro Pelado Member in which reddish sediments are more common. This stratigraphic distribution of the collected specimens was briefly presented by Barberena et al., 1980, 1985a,b).

Most laboratory preparation of the type series and referred material was carried out still during the 1980s at UFRGS mainly by Mr. Valdor Costa†. Additional preparation was performed during this study. Small needles were used to remove matrix from some foramina and sutures. The quality of preservation is remarkable on the isolated mandibles where many details are clear. On the other hand, the preservation of the skull UFRGS-PV-0352-P is comparatively poor. The difficulty to see some mandibular features directly on this specimen, especially those of the lower jaw lingual side, was partially solved by the CT-Scan images, and leads us to gingerly consider it as referred material including it in the description of the species.

The morphological and size similarities observed among all the mandibular branches (including those associated with the skull UFRGS-PV-0352-P) and the fact that most were collected roughly at the same stratigraphic level lead us to consider, at first, that all these materials would belong to the same taxon, a hypothesis that was then tested through the use of additional tools (3D Scan and digital reconstructions). 
With this propose, the specimen (UFRGS-PV-0352-P) was submitted to CT-Scan analysis using a GE Bright Speed 16 channels medical CT scanner in a private medical clinic at Porto Alegre city, Rio Grande do Sul State, Brazil in order to try to reconstitute the left mandibular ramus that was attached to the skull especially on its lingual face. The CT data include 597 slices with a spacing of $0.625 \mathrm{~mm}$ that were obtained using a tube voltage of $140 \mathrm{kV}$ and a tube current of $49 \mathrm{~mA}$, being the data recorded in a DICOM file. The images were later processed using the software Avizo 7.1.

\section{SYSTEMATIC PALEONTOLOGY}

\author{
TEMNOSPONDYLI Zittel, 1888 \\ STEREOSPONDYLOMORPHA Yates \& Warren, 2000 \\ STEREOSPONDYLI Fraas, 1889 \\ RHINESUCHIDAE Watson, 1919 \\ Rastosuchus gen. nov. \\ urn:lsid:zoobank.org:act:A7513E9B-BA13-4E8B-BE40- \\ ECBDFA0CE6FA
}

Type species. Rastosuchus hammeri gen. et sp. nov.

1980 Rastosuchus hammeri Barberena, Correia \& Aumond (name only and thus nomen nudum).

2008 Rastosuchus hammeri Langer, Eltink Bittencour \& Rohn (declared as nomen nudum).

2012 Rastosuchus hammeri Eltink \& Dias (declared as nomen nudum).

Etymology. Rasto in reference to the Rio do Rasto Formation; suchus (Greek): crocodile-like animal.

Diagnosis. As for the type species, by monotypy.

Rastosuchus hammeri sp. nov. urn:lsid:zoobank.org:act:C10B30A7-032A-4E9C-86950CBD0EFC6A26

(Figures 2-15)

Etymology. hammeri in honor to Dr. William Roy Hammer, a paleontologist with important contributions to the knowledge of the vertebrate fauna from Gondwana. We maintain the aspiration of Dr. Mario C. Barberena $\dagger$ to make this homage.

Holotype. UFRGS-PV-0350-P left and right mandibular rami. Right lower jaw almost complete lacking the symphysial area and the posterior portion of the left lower jaw (Figures 2A-F).

Paratypes. UFRGS-PV-0349-P, an almost complete left lower jaw (Figure 3); UFRGS-PV-0235-P, an anterior mandibular fragment including the symphysial area (Figure $2 \mathrm{G}-\mathrm{J}$ ); UFRGS-PV-0357-P, an intermediate mandibular fragment (Figure 4). UFRGS-PV-0356-P is a set of elements of the same individual including a clavicle, cleithrum, scapulocoracoid, femur, disarticulated autopodial elements, disarticulated vertebral elements, fragmentary ribs and other unprepared postcranial elements (Figures 7-10).
Referred material. UFRGS-PV-0352-P, a partial skull preserved in ventral view with incomplete mandibles (Figures 11-15).

Strata and locality. The material was collected in several outcrops along the Ponta Grossa to Apucarana railway at the Serra do Cadeado region (Figure 1), Paraná State, Brazil, all in strata from the Morro Pelado Member of the Rio do Rasto Formation (Barberena et al., 1980). The specimens UFRGSPV-0235-P; UFRGS-PV-0350-P; UFRGS-PV-0352-P, UFRGS-PV-0356-P and UFRGS-PV-0357-P were collected in lower levels of the Morro Pelado Member at the same site denominated by M. C. Barberena (field notes) as "CT-12 Boca Sul" in reference to the railway tunnel 12 - south opening cut, in the Morro dos Mulatos, while UFRGS-PV-0356-P and UFRGS-PV-0357-P where found slightly below the specimens UFRGS-PV-0235-P, UFRGS-PV-0352-P and UFRGS-PV0350-P. The specimen UFRGS-PV-0349-P was also collected in the same Serra do Cadeado area but in upper levels of the Morro Pelado Member of the Rio do Rasto Formation. Langer et al. (2008) presents a new attempt to access these outcrops with more detailed maps and coordinates.

Diagnosis. Straight conical teeth at all three coronoid bones (not denticles) on a short-snouted lower jaw morphotype with anterior tip well curved medially; the anterior portion of the dentary with a horizontal shelf which bears one or two parasymphysial tusks; short symphysis; postsymphysial foramen present just below the dentary anterior shelf; anterior teeth of the dentary tooth row slightly smaller at the symphysial region; contact between prearticular and anterior splenial at the level of the anteriormost meckelian foramen and forward; prearticular participating on the dorsal edge of both anterior and posterior meckelian foramen; prearticular and precoronoid with a broad contact; anteriormost meckelian foramen enlarged and followed by two or more smaller foramina; labial wall of the adductor fossa slightly convex; presence of a large elongated posterior meckelian foramen bordered by postsplenial, angular and prearticular; a 'L-shaped' glenoid fossa (in dorsal view) situated above the level of the dentary (in lateral view); hamate process absent; the angular reaches the articular just below the glenoid fossa; an elongated and well-developed chorda tympanic foramen is placed mostly in the prearticular but in contact the prearticular and articular suture; postglenoid area short boss as long as the glenoid transversal portion and composed by surangular and articular; arcadian groove present; cervical and anterior intercentra are C-shaped, so without a dorsal connection and not form regular disks or spools, while intercentra of posterior trunk and caudal vertebrae are widely opened 'crescentshaped'; pleurocentra are laterodorsal elements not contacting each other ventrally; ribs with uncinate processes; clavicle with a short ventral blade which is almost a right triangle in ventral view; base of its ascending process with a posterior buttress and distally a rod-like ascending process slightly sigmoid in posterior and anterior views; femur with a strong finger-like internal trochanter and a shallow intercondylar fossa tendinalis (shared with Australerpeton cosgriffi but slightly deeper in Rastosuchus hammeri gen. et sp. nov.). 

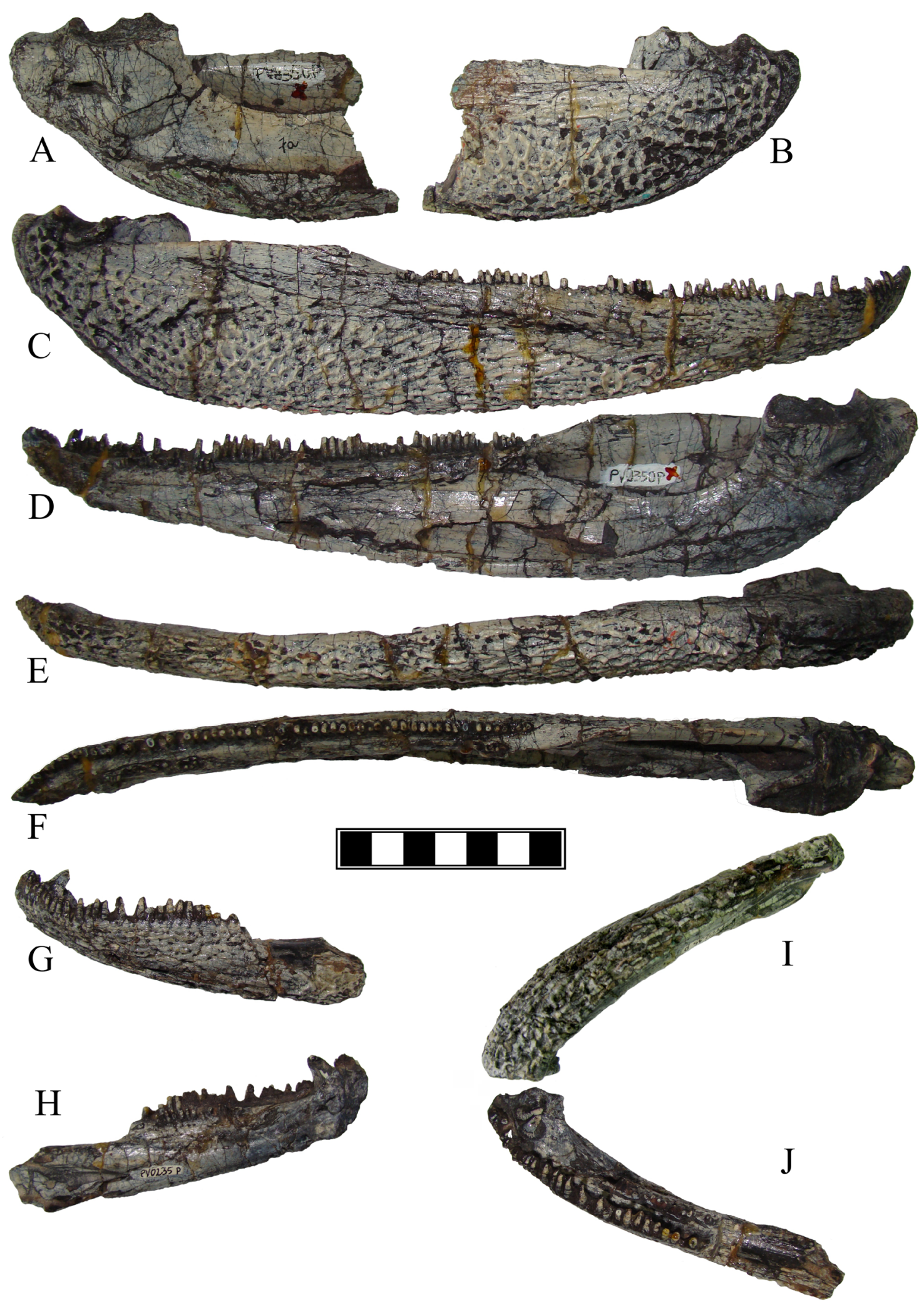

Figure 2. Lower jaws of Rastosuchus hammeri gen. et sp. nov. A-F, holotype (UFRGS-PV-0350-P). A, lingual view; B, labial view of the left ramus (UFRGSPV-0350b-P). C, labial view of the right ramus (UFRGS-PV-0350a-P); D, lingual view; E, ventral view; F, dorsal view of the right ramus. G-J, fragment of the anterior portion of a lower jaw with symphysial area preserved (UFRGS-PV-0235-P). G, labial view; H, lingual view; I, ventral view; J, dorsal view, showing two tusks close to each other near the symphysis. In UFRGS-PV-0350a-P (D, F) precoronoid and coronoid with dentition partially preserved while intercoronoid is damaged. In UFRGS-PV-0235-P $(\mathbf{H}, \mathbf{J})$ dentition on the precoronoid complete. Scale bar $=7 \mathrm{~cm}$. 


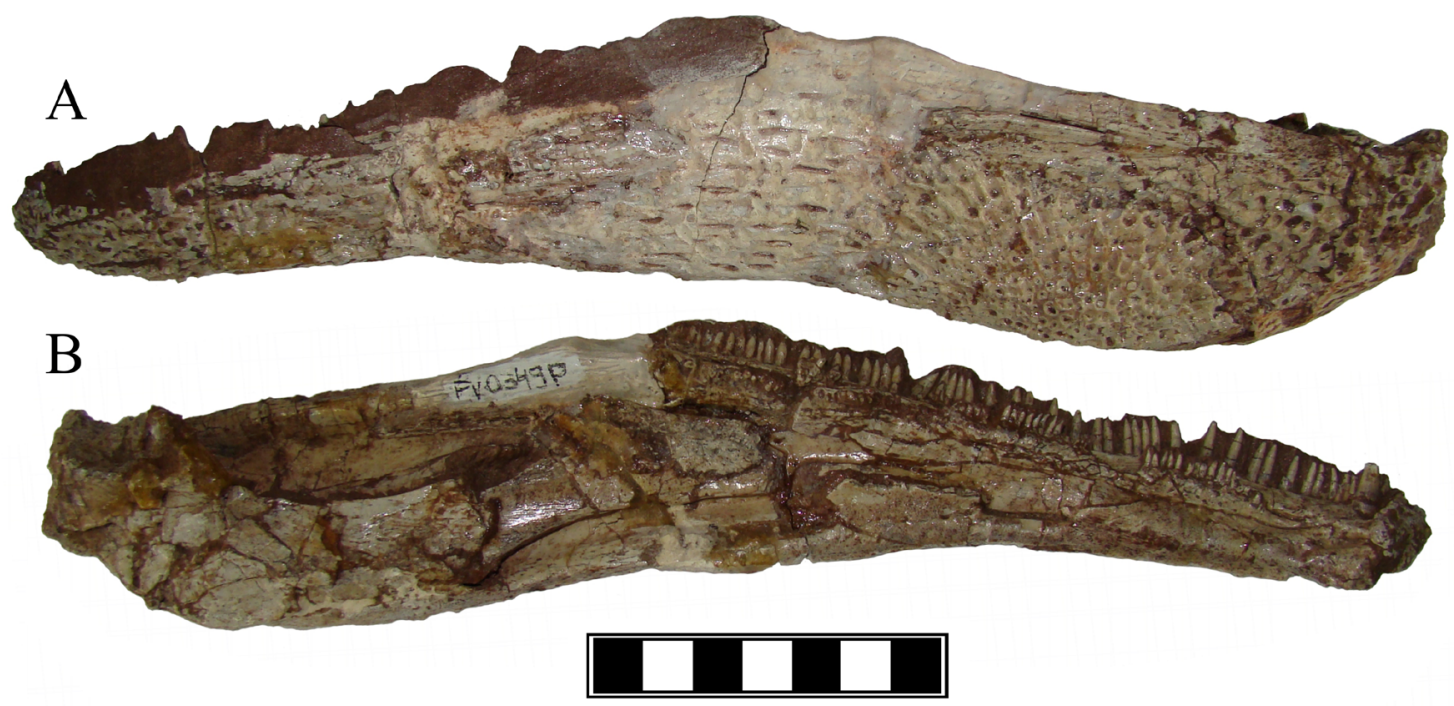

Figure 3. Isolated mandible of Rastosuchus hammeri gen. et sp. nov. (UFRGS-PV-0349-P) with median portion reconstructed with some plaster. A, labial view with dentition covered by sedimentary matrix and middle portion with a plaster reconstruction; $\mathbf{B}$, lingual view with dentition exposed including those of the coronoid series. Symphysial area presenting a single tusk. Glenoid and postglenoid portion bad preserved. Scale bar $=7 \mathrm{~cm}$.

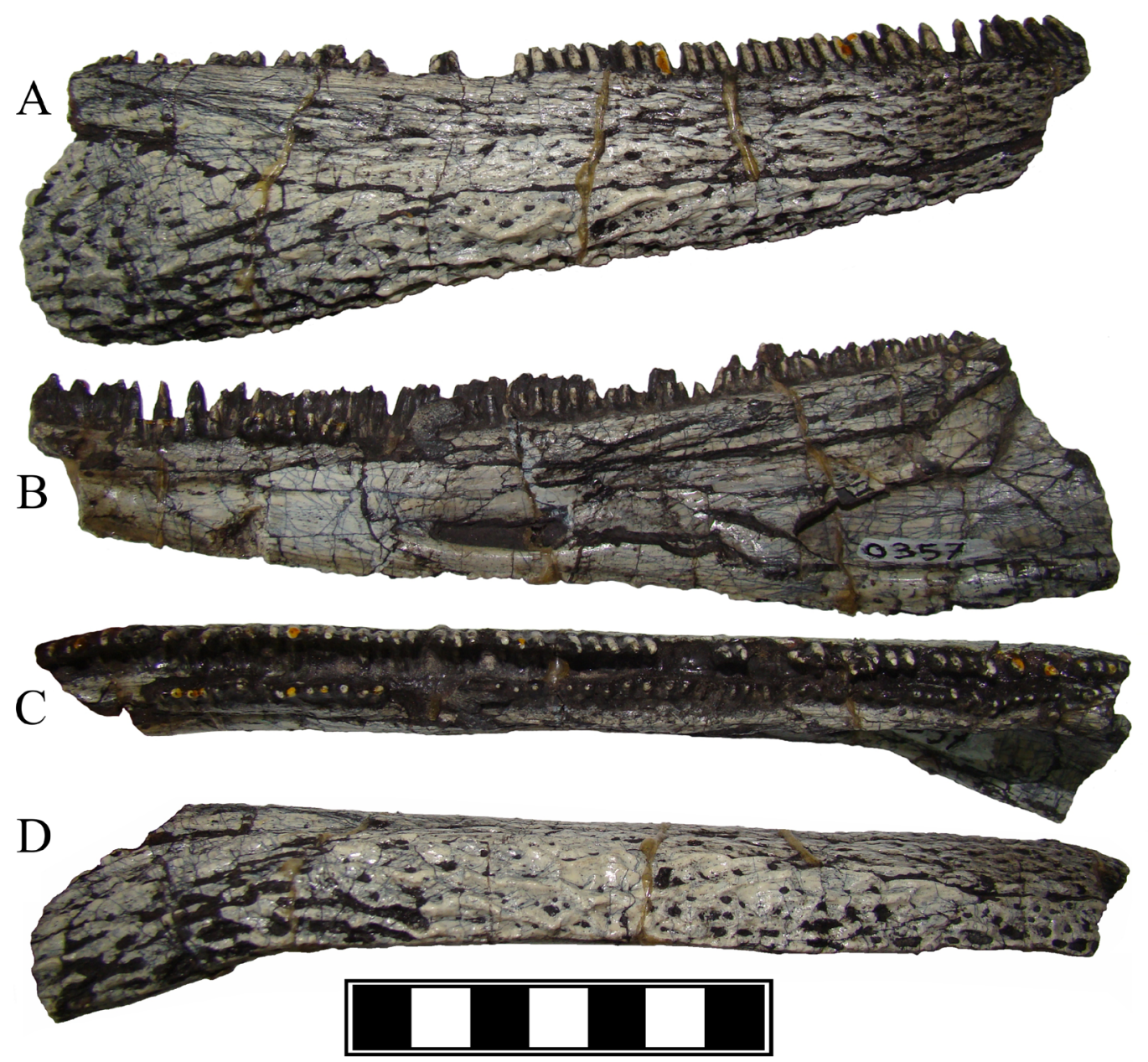

Figure 4. Median portion of a right mandible of Rastosuchus hammeri gen. et sp. nov. (UFRGS-PV-0357-P). A, labial view showing clear suture lines and bone ornamentation; $\mathbf{B}$, lingual view with a well-preserved anterior meckelian foramen; $\mathbf{C}$, dorsal view showing the dentition of the dentary and of the coronoid series, forming a complete double tooth row; $\mathbf{D}$, ventral view of the dentary. Scale bar $=7 \mathrm{~cm}$. 

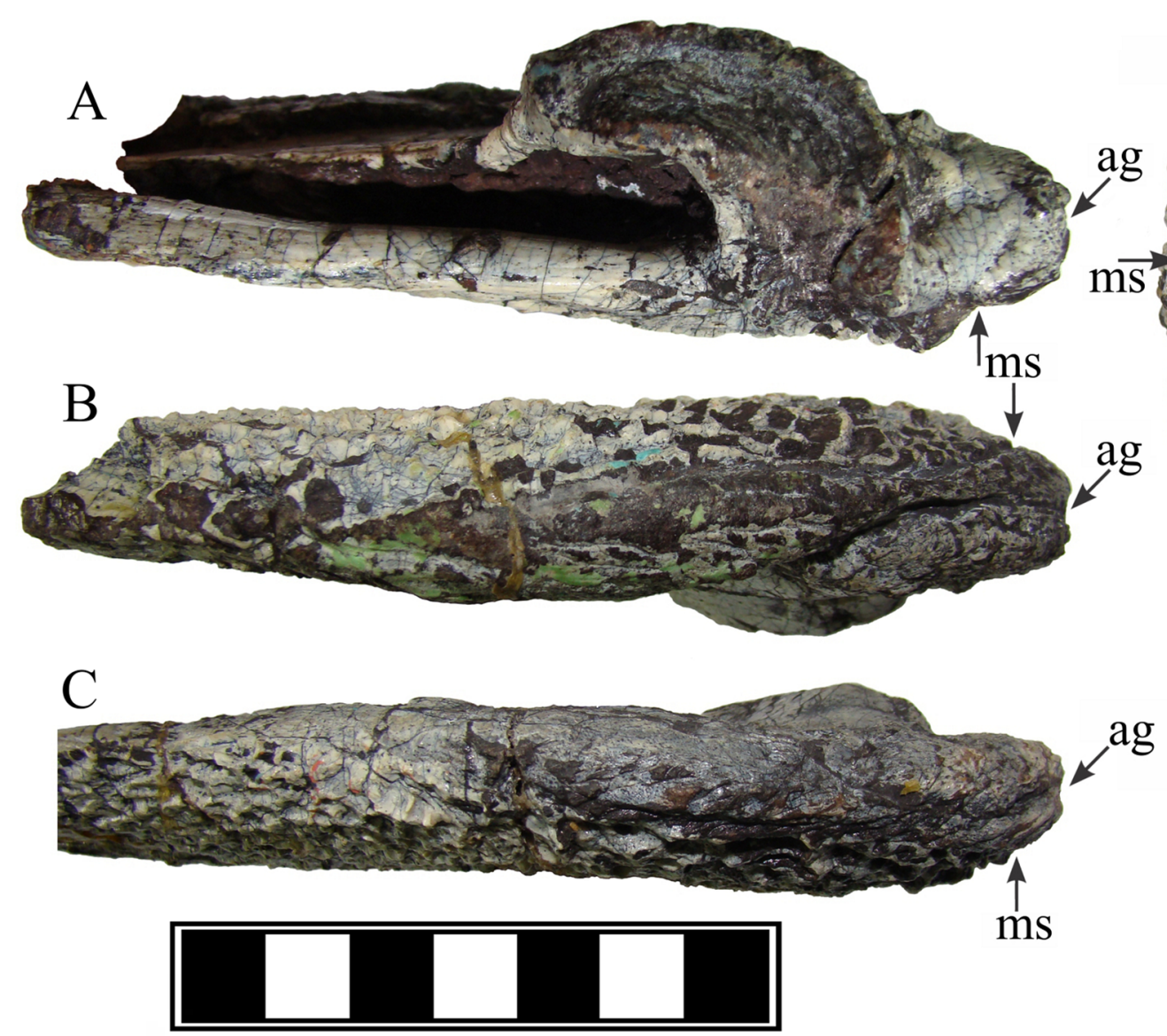

Figure 5. Detail of the mandible of Rastosuchus hammeri gen. et sp. nov. showing the arcadian groove and the mandibular sensory sulcus. A, left ramus in dorsal view (UFRGS-PV-0350b-P) showing L-shaped glenoid cavity; B, left ramus in ventral view (UFRGS-PV-0350b-P); C, right ramus in ventral view (UFRGS-PV-0350a-P); D, left ramus in posterior view (UFRGS-PV-0350b-P). Abbreviations: ag, arcadian groove (white arrow in D); ms, mandibular sulcus. Scale bar $=7 \mathrm{~cm}$.

Historical remarks. Rastosuchus hammeri (name only) was previously mentioned by Barberena et al. (1980) as "an incoming publication that would formally present a short-snouted temnospondyl with affinities to African rhinesuchoids", collected in the Rio do Rasto Formation at the Serra do Cadeado area in the Paraná State, Southern Brazil. Later, this name was mentioned in some stratigraphic and biostratigraphic studies such as Daemon et al. (1996) and Stollhofen et al. (2000). However, a formal description of this taxon was never carried out until this contribution. Thus, Rastosuchus hammeri remains, until now, as nomen nudum (Langer et al., 2008; Eltink \& Dias, 2012). As this name was mentioned in other publications as an important biostratigraphic evidence to correlate South
American and South African units, we prefer herein to validate Rastosuchus hammeri rather than create a new denomination, in agreement with the definition of nomen nudum on the Glossary of the International Code of Zoological Nomenclature (Ride et al., 1999). Barberena \& Dias (1998) presented a preliminary description of a short-snouted with no formal denomination and here that specimen (UFRGS-PV-0352-P) is referred to Rastosuchus hammeri gen. et sp. nov. Dias \& Kroeff (2002) also presented preliminary studies on the short-snouted temnospondyl based on a series of mandibular elements from the Rio do Rasto Formation, also without a formal denomination and most of those specimens are here related to Rastosuchus hammeri gen. et sp. nov. 


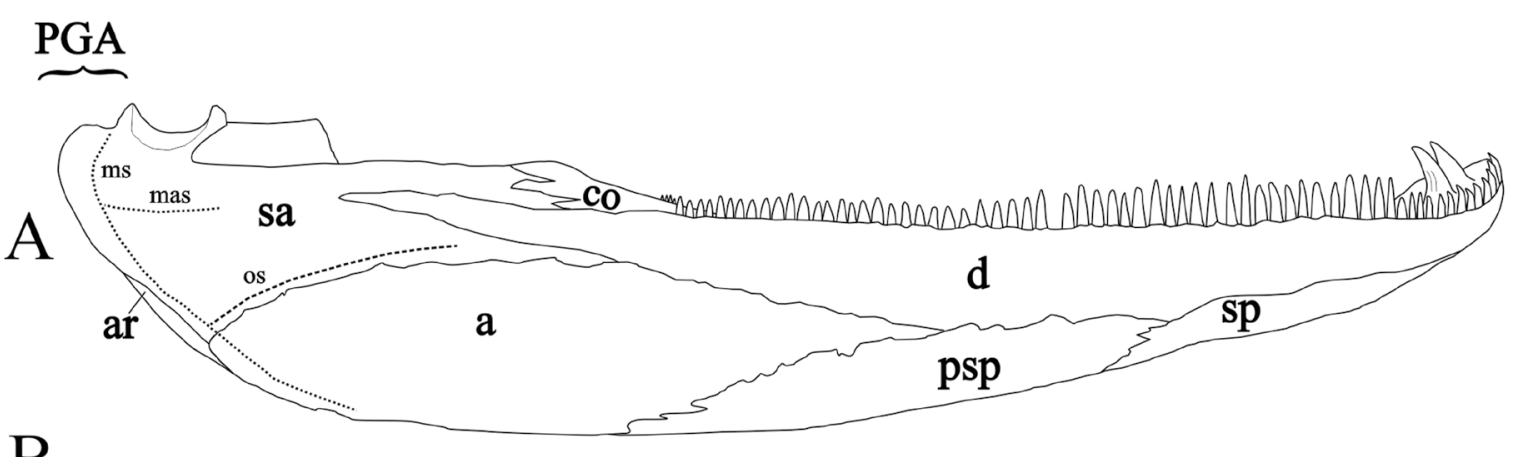

$\mathrm{B}$

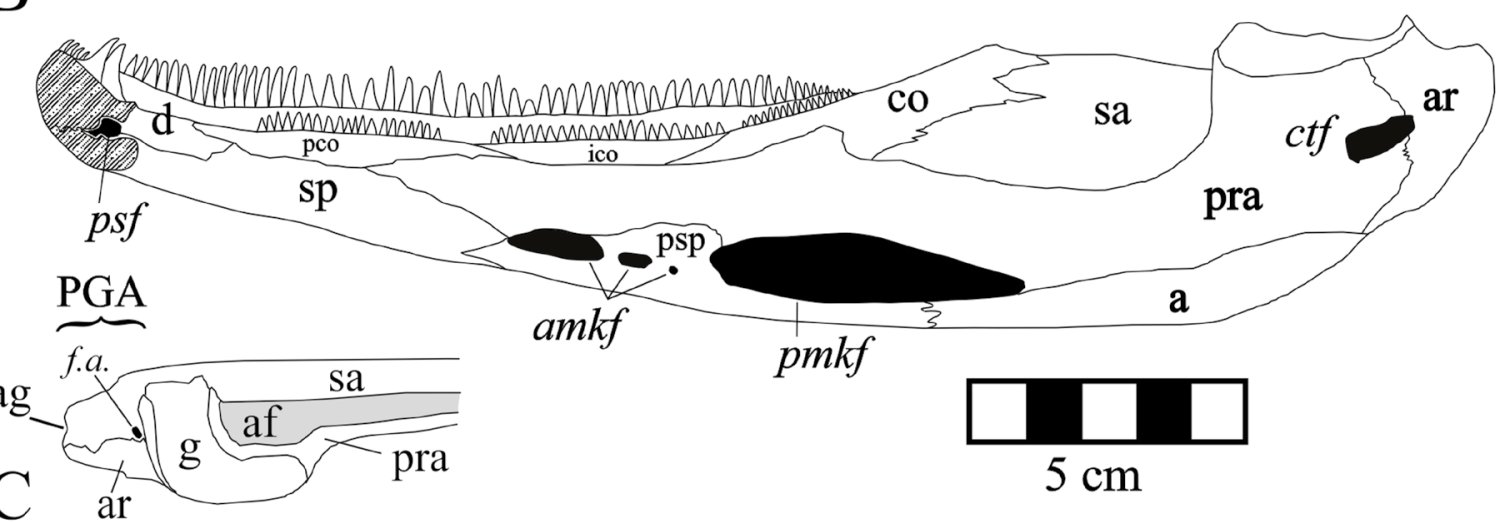

Figure 6. Lower jaw reconstruction of the Rastosuchus hammeri gen. et sp. nov. A, labial view; B, lingual view; C, dorsal view of the glenoid area. Abbreviations: a, angular; af, adductor fossa; ag, arcadian groove; amkf, anterior meckelian foramina; ar, articular; ctf, chorda tympanic foramen; co, coronoid; d, dentary; f.a., aerum foramen(?); g, glenoid cavity; ico, intercoronoid; pco, precoronoid; PGA, postglenoid area; pra, prearticular; psp, postsplenial; psf, postsymphysial foramen; sa, surangular; sp, splenial; pmkf, posterior meckelian foramen. Dashed lines: ms, mandibular sensory sulcus; mas, mandibular accessory sensory sulcus; os, oral sensory sulcus. Scale bar $=5 \mathrm{~cm}$.

\section{DESCRIPTION}

The preservation of mandibular and associated postcranial elements is remarkable. The dermal bones have reticulated ornamentation composed by concentric ridges surrounding or enclosing the depressions (pit and furrows). Most bones and sutural contacts, dentition, foramens and fenestrae are visible in some extent in the mandibles of Rastosuchus hammeri gen. et sp. nov.

Mandible (Figures 2-6). Due to their excellent state of preservation, the mandibles are the most representative material assigned to Rastosuchus hammeri gen. et sp. nov. As previously stated, the mandibular morphology of the new taxon is based on a composite reconstruction of the type series, as no mandibular material is complete. Regarding their size, the mandibles of the type series range from $25 \mathrm{~cm}$ in UFRGSPV-0349-P to $27 \mathrm{~cm}$ long as estimated based in UFRGS-PV0350-P and UFRGS-PV-0235-P. Rastosuchus hammeri gen. et sp. nov. presents dentition (teeth rather than denticles) on all three bones of the coronoid series (Figures 2D, F, H, J, 3B) forming a discontinuous lingual tooth row (Figures 4B, $\mathrm{C}, 6 \mathrm{~B})$. The dentition covers almost the entire extension of precoronoid and intercoronoid, but in the coronoid it is restrict to the anterior half of the bone. In UFRGS-PV-0235-P 15 teeth are present in the precoronoid while in UFRGS-PV-
0349-P and UFRGS-PV-0357-P the precoronoid presents 15 teeth, the intercoroniod around 16-17 and the coronoid around 18-19. In UFRGS-PV-0350a-P a number close to 15 teeth should be present in the precoronoid, but the area is broken and only nine teeth are preserved. Only three teeth are preserved in the coronoid of UFRGS-PV-0350a-P that is also anteriorly broken and its intercoronoid mostly damaged. None of the three coronoids present denticles. Anteriorly, in the short symphysial region, one (UFRGS-PV-0349-P) or two tusks (UFRGS-PV-0235-P) are present (Figures 2G-H, J, 3 ). The presence of one or two tusks on the symphysial shelf may represent differences in the ontogenetic stage or simply replacement stages (Schoch \& Milner, 2000). The tusks of UFRGS-PV-0235-P have the same size, and are placed very close to each other, without a clear evidence of replacement. A hamate process is absent. The postglenoid area (PGA sensu Jupp \& Warren, 1986) is conspicuous but short, and presents an arcadian groove (sensu Jupp \& Warren, 1986). The arcadian groove separates the arcadian process and the postglenoid process, both are small and similar in size (Figures 5A-D, 6C).

Mandible in labial view (Figures 2B-C, 3A, 4A, 6A). The anterior region near the symphysis is composed ventrally by the splenial and dorsally by the dentary. The splenial extends backward to contact ventrally the postsplenial, which is dorsally limited by the dentary and anteriorly by 

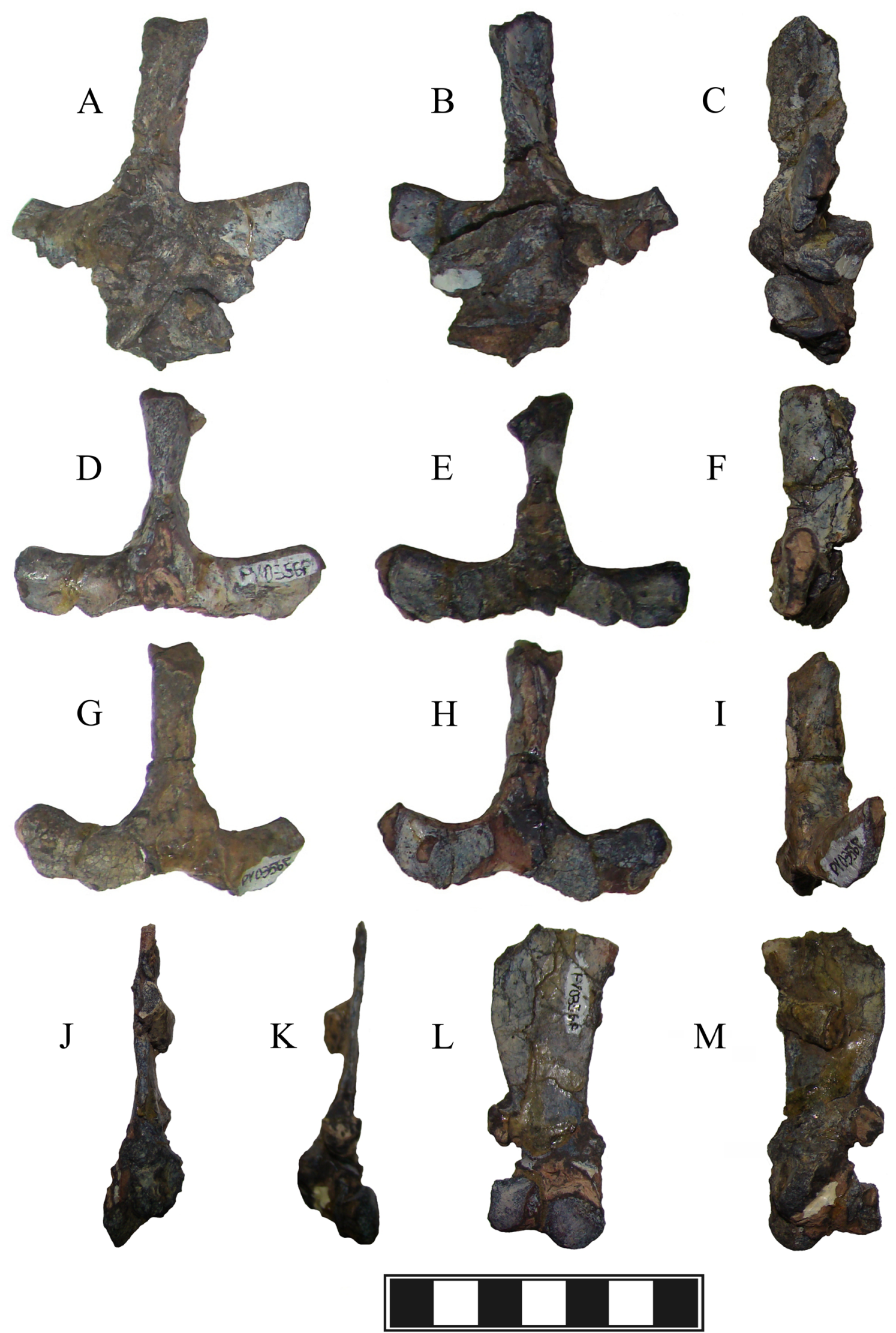

Figure 7. Selected vertebral elements of Rastosuchus hammeri gen. et sp. nov. (UFRGS-PV-0356-P) - neural arches. A, D, G, J, anterior view; B, E, H, K, posterior view; $\mathbf{C}, \mathbf{F}, \mathbf{I}, \mathbf{M}$, lateral view; $\mathbf{L}$, lateral view with part of the neural canal. Scale bar $=7 \mathrm{~cm}$. 

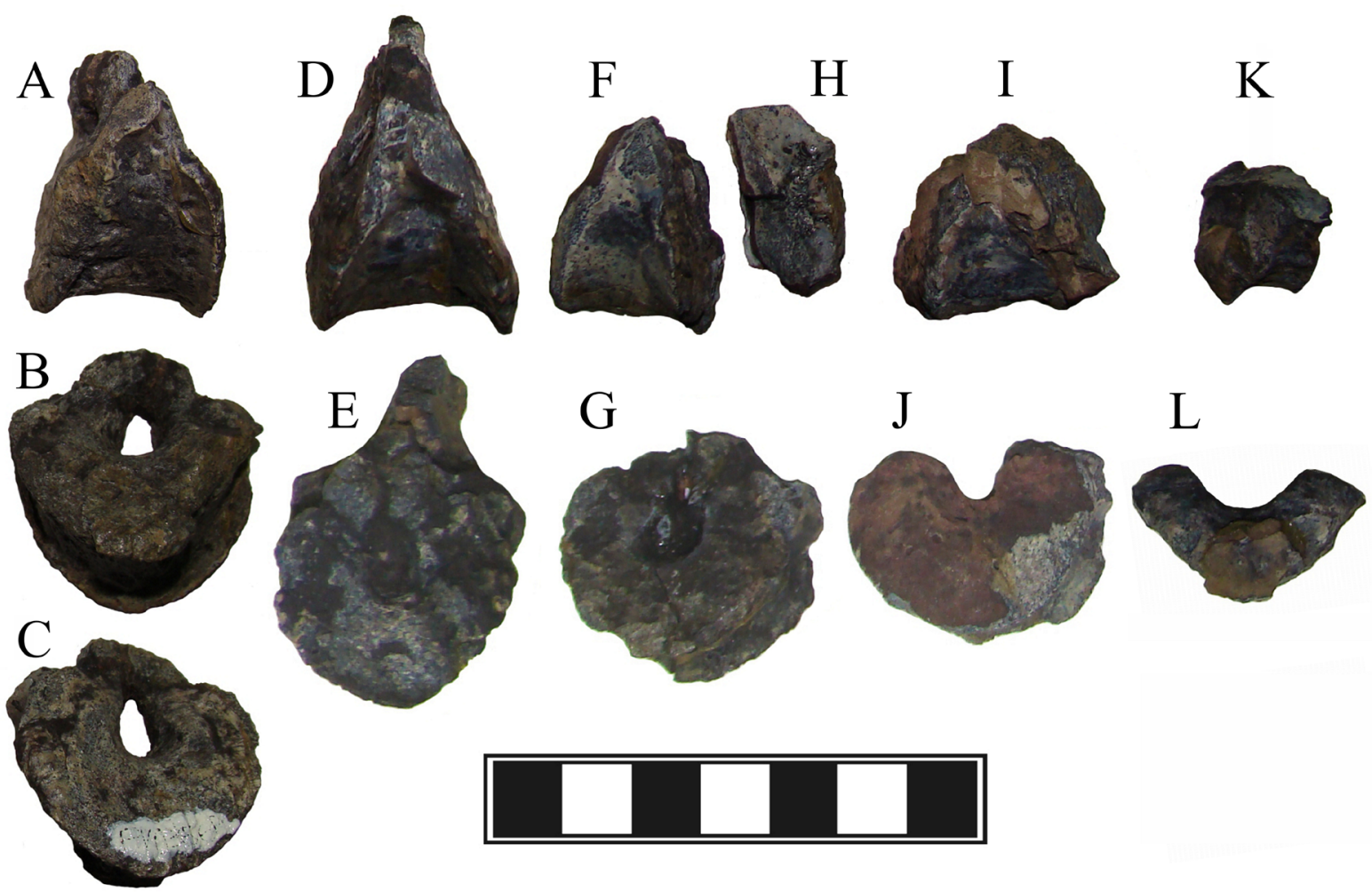

Figure 8. Selected vertebral elements of Rastosuchus hammeri gen. et sp. nov. (UFRGS-PV-0356-P) - vertebral centra. A-G, crescent-shape intercentra almost connected dorsally living a chordal canal opening $(\mathbf{B}, \mathbf{C}$, with part of one pleurocentrum and $\mathbf{E}, \mathbf{G}$, with bone fragments, on both cases attached not in anatomical position). $\mathbf{H}$, pleurocentrum in lateral view. $\mathbf{I}-\mathbf{L}$, crescent-shaped intercentra with broad dorsally open chordal canal. Scale bar $=7 \mathrm{~cm}$.

the splenial (Figures 2C, 4A, 6A). The dentary extends from the symphysial area to the wall of the adductor fossa, comprising $80 \%$ of the total length of the mandible. The posterior portion of the dentary is a toothless wedge-shaped narrow lamina that partially covers the surangular, just below the dorsal border of the adductor fossa, so the dentary presents a single posterior process suturing with the surangular. The dentary teeth are conical and slightly anteroposteriorly compressed. The posterior portion of the coronoid is toothless, and in labial side it composes part of the dorsal border of the lower jaw and the anteriormost border of the adductor fossa (Figures 2C, 6A). The surangular sutures with the coronoid and extends backward, composing the posterior dorsal border of the adductor fossa wall, forming a slightly convex crista arcuata, and run backward to the PGA. At the crista arcuata the surangular is thicker composing the torus arcuatus. Surangular extends forward between angular and the dentary posterior process (Figure 6A). Posteroventrally, a small portion of the surangular-articular suture is observable in labial view (Figures 2C, 6A). The angular is located just below the surangular and composes the ventral border of the lower jaw, below the adductor fossa. The anterior border of the angular sutures with the postsplenial turning downward to the lingual side of the mandible (Figures 2B-D, 4A, 6A-B). Posteriorly, the angular reaches the articular exactly below the glenoid fossa, one of the features of a PGA type I sensu Jupp $\&$ Warren (1986). Three smooth sensory sulci occur on the surangular: the mandibular, the mandibular accessory and the oral sulcus. The mandibular sensory sulcus begins posteriorly to the glenoid fossa at medial portion of the PGA in labial view (Figures 5A-D). The mandibular sensory sulcus slopes downward through the angular running parallel to the ventral curvature of the lower jaw, where the remaining sensory sulci (oral and mandibular accessory) bifurcate and project anteriorly, both over the surangular (Figure 6A). According to Jupp \& Warren (1986), this sensory sulci configuration is also plesiomorphic and usual within temnospondyls.

Mandible in lingual view (Figures 2A, D, H, 3B, 4B, 6B). The symphysial region is composed by the splenial ventrally and the dentary dorsally. The splenial extends backward to ventrally contact the postsplenial just anteriorly to the anterior meckelian foramen. Outside the symphysial area, the dorsal limit of the splenial is with the precoronoid and posterodorsally it contacts the anteriormost border of the prearticular. The suture between splenial and prearticular anteriorly contacts the precoronoid and runs backward to the level of the anterior meckelian foramen (Figures 2D, 3B, 4B, $6 \mathrm{~B})$. The symphysial area presents a nearly horizontal shelf (Figure 2H, J) which holds one (UFRGS-PV-0349-P) or two (UFRGS-PV-0235-P) large parasymphysial tusks which are gently curved posteriorly toward the oral cavity (Figures $2 \mathrm{G}-$ $\mathrm{H}, 6 \mathrm{~A}-\mathrm{B})$. A well-developed oval postsymphysial foramen is located above this horizontal shelf (Figures $2 \mathrm{H}, 3 \mathrm{~B}, 6 \mathrm{~B}$ ). The dentary covers the anterior half of the dorsal margin of the mandible, bearing 50 teeth in UFRGS-PV-0349-P and 65 teeth in UFRGS-PV-0350a-P. The precoronoid, intercoronoid 


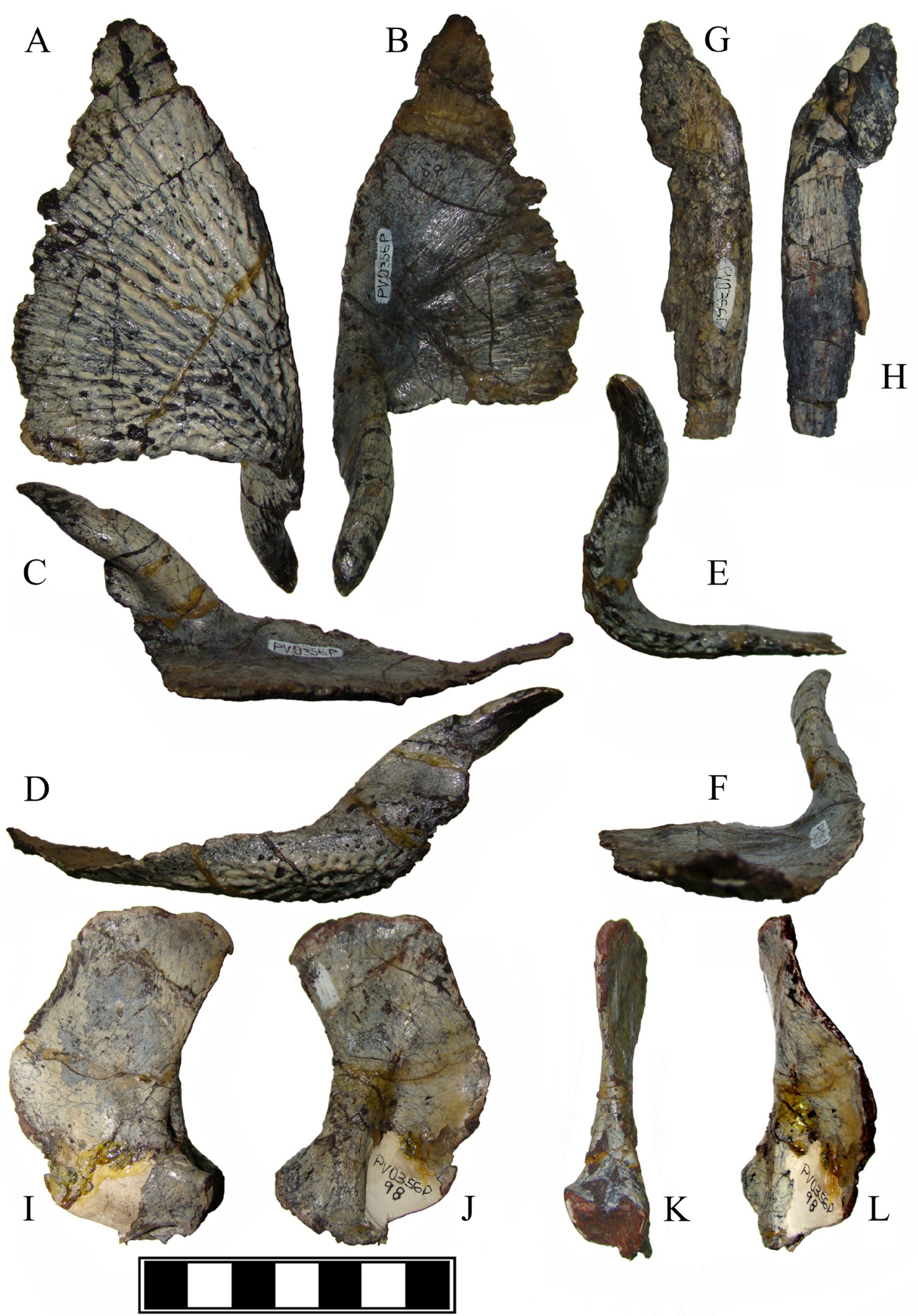

Figure 9. Shoulder girdle elements of Rastosuchus hammeri gen. et sp. nov. (UFRGS-PV-0356-P). A-F, left clavicle. A, ventral; B, dorsal; C, medial; D, lateral; E, posterior; F, anterior views. G-H, cleithrum. I-L, left scapulocoracoid. I, lateral; J, medial; K, posterior; $\mathbf{L}$, anterior views. Scale bar $=7 \mathrm{~cm}$. 
and coronoid are sheets of dermal bone that cover the dorsolingual surface of the dentary. As already mentioned, all three coronoids bear straight, dorsally projected conical teeth, as observed in the specimens UFRGS-PV-0349-P, UFRGSPV-0357-P, and in UFRGS-PV-0350a-P the intercoronoid is deeply damaged, so only in the precoronoid and medial portion of the coronoid the dentition can be observed in dorsal view (Figure 2D, F, H, J, 3B, 4B-C). The tooth bearing coronoid series form a discontinuous tooth row parallel to the dentary dentition (Figure 6B). The precoronoid sutures ventrally with the splenial and the anterior border of the prearticular. The intercoronoid contacts ventrally the prearticular, and the coronoid contacts ventrally the prearticular and the surangular (Figure 6B). The anteroventral mandibular region is composed of the splenial and postsplenial in lingual and labial view. On the anterior portion of the postsplenial, at least two anterior meckelian foramina are present, the anteriormost is bigger and dorsally limited by the prearticular, whereas the others are completely inside or surrounded by the postsplenial (Figure 6B). The prearticular contacts the splenial at the level of the anterior border of the most anterior meckelian foramen. The anterior region of the prearticular is elongated with an acute anterior end (knife-shaped) that is better preserved in UFRGS-PV-0235-P (Figure 2H) and UFRGS-PV-0349-P (Figure 3B), suturing anteroventrally with the splenial and anterodorsally with the precoronoid on its ventral/posterior portion (Figure 6B). Posteriorly, the prearticular forms the internal wall of the adductor fossa and the superior margin of the posterior meckelian foramen. The prearticular also contributes to a dorsal projection on the anterior border of the glenoid fossa, which is above the level of the labial wall of the adductor fossa, but not high enough to configure a definite hamate process, composing the L-shaped glenoid in dorsal view. The prearticular does not extend posteriorly to the glenoid cavity level. The posterior meckelian foramen is elliptical, elongated and placed very close to the ventral border of the mandibular ramus (Figures 2D, 3B, 4B). Its margins are composed of the prearticular dorsally, whereas by the postsplenial anteriorly and ventrally, and angular ventroposteriorly (Figure 6B). According to Nilsson (1944) this foramen is related to the mylohyoid nerve, artery, vein, so it cannot be considered as a fenestra. The angular composes the posteroventral border of the lower jaw extending posteriorly to sutures with the articular. It is important to point out that, in lingual view, neither the angular nor the prearticular extend beyond the anterior limit of the postglenoid area, so the PGA is only composed by the articular and surangular (Figure 6). In UFRGS-PV-0350a-P and UFRGS-PV-0350b-P the welldeveloped chorda tympanic foramen for the chorda tympani nerve (Nilsson, 1944) is elliptical, with approximately $0.8 \mathrm{~mm}$ in its maximum opening and mostly located in the prearticular, and presents a small posterior contact to the prearticulararticular suture (Figures 2A, D, 3B, 6B).

Mandible in dorsal view (Figures 2F, J, 4C, 5A, 6C). A noteworthy feature in dorsal view is the completion of tooth rows over the dentary and coronoid series (Figure 4C). Presumably, they match the parallel tooth rows of premaxillary/maxillary and palatine/ectopterygoid dentition to form a double line of occlusion. In the symphysial region, posteriorly to the dentary tooth row, the short platform is seen completely only on UFRGS-PV-0235-P (Figures 2G, H, J). The first 8-10 anterior teeth of dentary tooth row are slightly smaller than the posterior ones, so the dentary teeth increase in size posteriorly to the symphysial region, a character shared with Australerpeton cosgriffi and Rhinesuchus whaitsi within the Rhinesuchidae. The 'L-shaped' glenoid surface is remarkable in dorsal view (Figures 2F, 5A, 6C). It is formed by the posterodorsal projection of the prearticular, as well as dorsal portions of the articular and surangular. This elevated portion is not interpreted as hamate process once its entire dorsal surface seems to have been part of the articulation surface.

Postglenoid area (PGA). The PGA of Rastosuchus hammeri gen. et sp. nov. is a short boss as long as the transversal portion of the glenoid cavity (Figures 5A, 6C). It is slightly bigger than in Rhineceps, but not as well-developed as in stereospondyls such as Chomatobatrachus. The PGA of $R$. hammeri gen. et sp. nov. is composed of the surangular labially, articular lingually, and the angular and prearticular do not extend to the PGA, a condition that characterizes a PGA type I sensu Jupp \& Warren (1986). A remarkable feature is the fact that the PGA of $R$. hammeri gen. et sp. nov. does not rise over the level of the highest portion of the glenoid fossa (Figures 2A-D, 6A-B). The PGA presents a shallow transverse trough behind the glenoid fossa followed by a gentle dorsal bulging tip. A small foramen in the bottom of this transverse trough is present which is probably equivalent to the foramen indicated as $f . a$. by Getmanov (1979), and similar in position to the articular aerum foramen present in some crocodilians (Brochu 1999; Bona \& Desojo 2011). Damiani et al. (2001) described an unnamed similar foramen for a South African sample attributed to Watsonisuchus. This foramen in $R$. hammeri gen. et sp. nov. is close to the suture between surangular and articular which is dorsally visible crossing the PGA longitudinally (Figures 5A, 6C). The articular is the main component of the PGA in lingual view, covering almost $50 \%$ of the PGA ventrally and dorsally. Labially, the surangular composes the PGA, comprising half of its ventral and dorsal surfaces. Finally, the postglenoid and arcadian processes are present, and between them, there is a shallow arcadian groove (Figure 5A) that becomes deeper ventrally (Figure 5B-D).

Postcranial elements. The postcranial elements of Rastosuchus hammeri gen. et sp. nov. correspond to a set of elements (UFRGS-PV-0356-P) including a clavicle, cleithrum, scapulocoracoid, femur, tibia, fibula, several disarticulated vertebral elements, fragmentary ribs, some autopodial elements.

Axial skeleton (Figures 7,8). The vertebral remains comprise isolated elements of the set UFRGS-PV0356-P, including neural arches, pleurocentra and intercentra. The neural arches vary mainly on its neural spines. Some of the neural spines presents width of the shaft almost similar to its anteroposterior dimension with well-developed distal lateral expansion for ligament insertions that form a cross-shaped transverse section (Figures 7A-I). On the other hand, there are laminar-shaped laterally compressed neural spines with the 


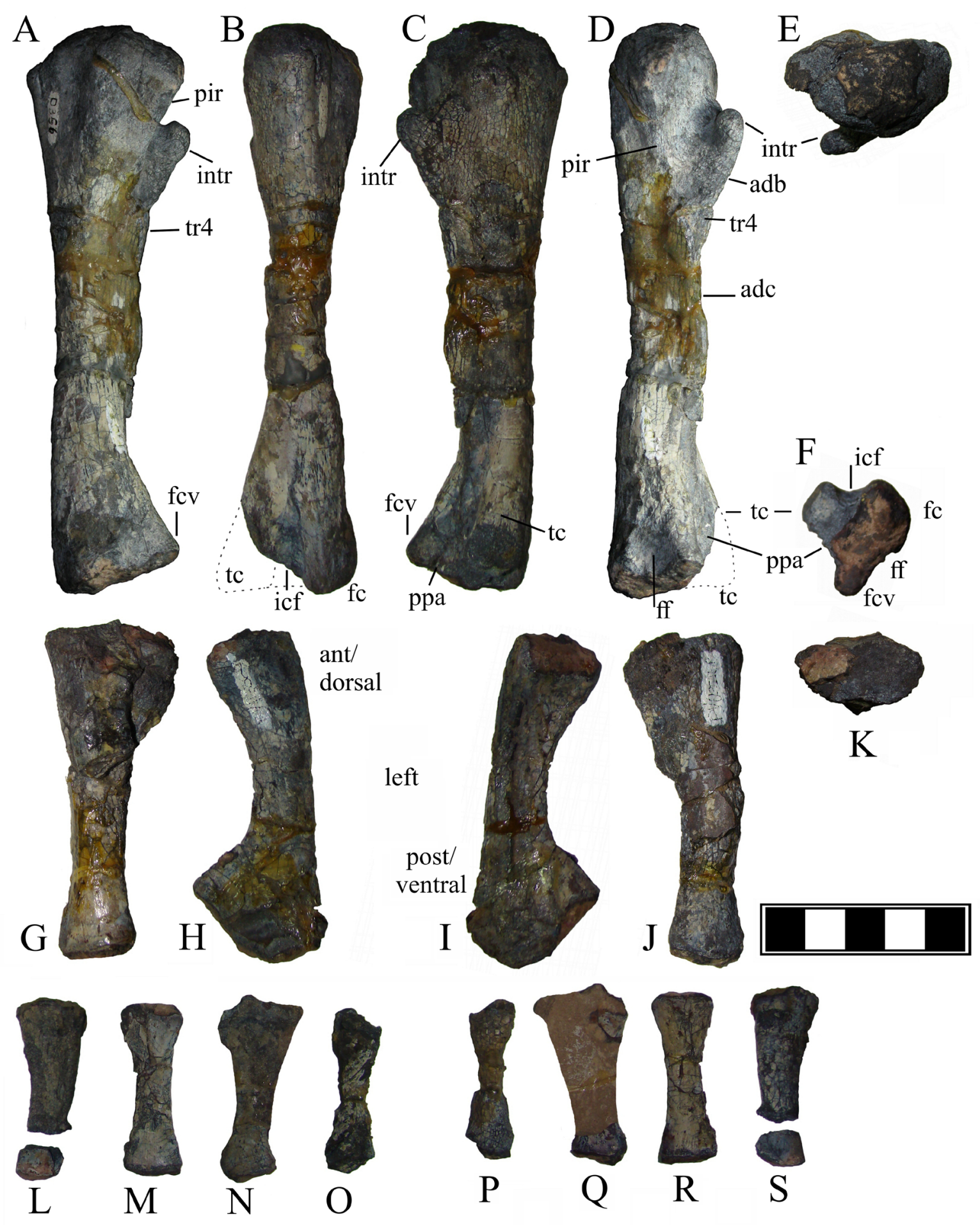

Figure 10. Hind limb elements of Rastosuchus hammeri gen. et sp. nov. (UFRGS-PV-0356-P). A-D, left femur: A, posterior, B, dorsal, C, anterior, D, ventral views; E, femur head in proximal view, F, femur in distal view, both anatomically oriented; G, J, left tibia; H, I, left fibula; K, left tibia on proximal view anatomically oriented; $\mathbf{L}-\mathbf{O}$, a set of metatarsals, and $\mathbf{P}-\mathbf{S}$, the same set of metatarsals in opposite view. Abbreviations: adb, adductor blade; adc, adductor crest; fc, fibular condyle; fcv, fibular condyle ventral portion; ff, fibular fossa; icf, intercondylar fossa; intr, internal trochanter; pir, posterior intertrochanteric ridge; ppa, popliteal concave area; tc, tibial condyle; tr4, fourth trochanter. Scale bar $=5 \mathrm{~cm}$.

ligament insertion limited to a small lateral ridge and broad anteroposterior dimension (Figures $7 \mathrm{~J}-\mathrm{M}$ ). Some almost complete neural arches present its dorsal end apparently fully ossified. The intercentra are triangular in lateral view and none of them comprise regular disks or spools (Figure 8). The intercentra are crescent-shaped elements that varies from almost dorsally closed (without a dorsal connection) living a narrow dorsal chordal opening in the cervical 

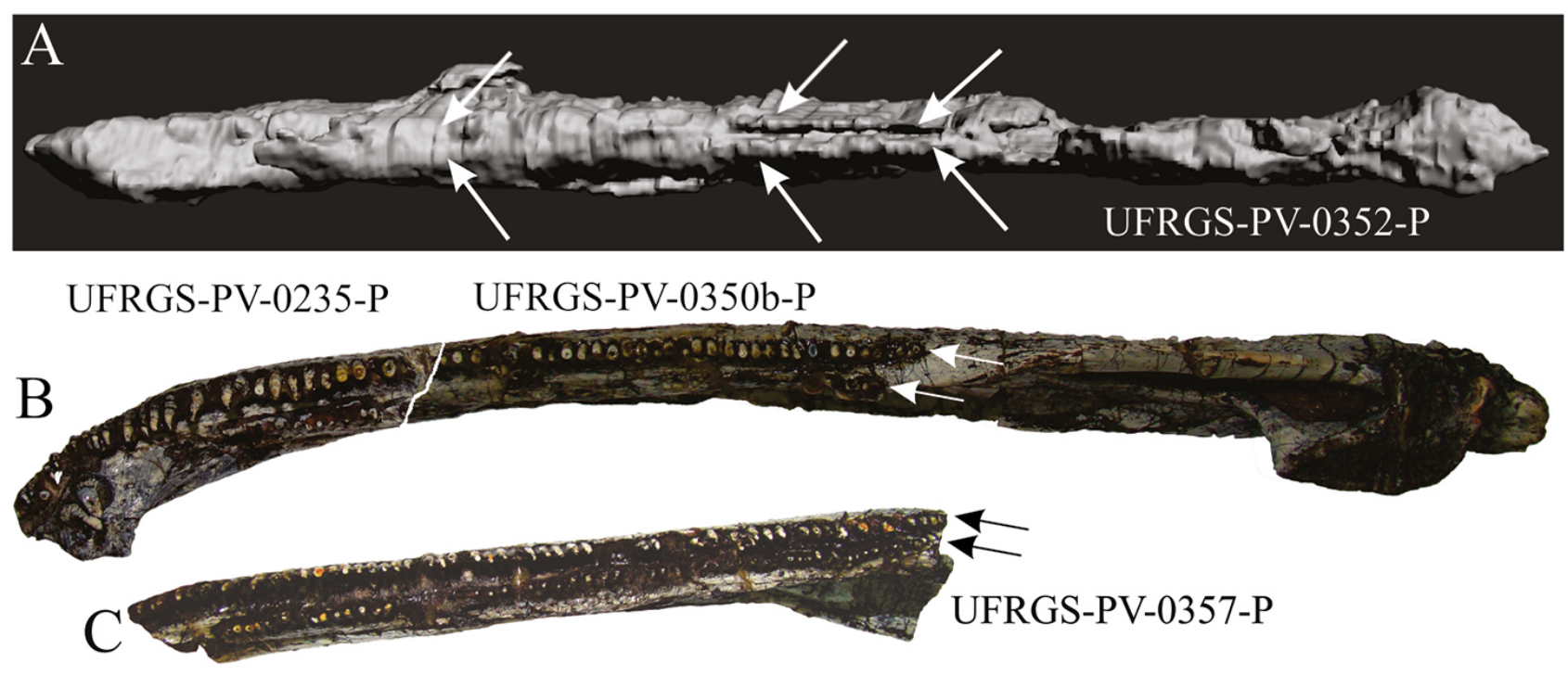

Figure 11. Comparison based on four specimens at the same anatomical orientation and alignment. A, image of the right mandible virtually detached from the CT-Scan of the specimen UFRGS-PV-0352-P. White arrows point to the tooth rows of the dentary (above) and coronoid (below). B, photomontage to compose a complete mandible of Rastosuchus hammeri gen. et sp. nov. based on specimens UFRGS-PV-0235-P (image of symphysial portion to the end of the precoronoid, inverted to be right), and UFRGS-PV-0350a-P (cut at the level of precoronoid ending). C, UFRGS-PV-0357-P with indications of the coronoid dentition. Not to scale.

and anterior trunk vertebrae (Figures $8 \mathrm{~A}-\mathrm{G}$ ), to a broadly opened crescent in the smaller elements of the posterior trunk and caudal vertebrae (Figures 8I-L). Considering the pleurocentra and intercentrum in anatomical position, the chordal canal is narrower than the intercentrum hight on the anterior vertebrae. The pleurocentra are small, paired 'kidney-shaped' bones attached to the neural arch (Figures $7 \mathrm{~A}-\mathrm{C})$ that in lateral view are smaller than corresponding intercentra (Figure 8H). Pleurocentrum presents articular surfaces for the anterior intercentra anteroventrally; for the posterior intercentra posteroventrally; and for the anterior neural arches anterodorsally. The pleurocentra are paired elements with evidence of contact to each other only dorsally, and they do not extend ventrally (Figure $8 \mathrm{H}$ ), so the ventral edges of the adjacent intercentra could contact each other. The ribs preserved are fragmentary, but the presence of uncinate process is clear which are blade-like structures.

Shoulder Girdle (Figure 9). The left clavicle of UFRGSPV-0356-P (Figure 9A-F) presents a short ventral blade of ornamented dermal bone, forming an almost right triangle in ventral view. The ventral surface of the clavicular blade is ornamented with narrow ridges separated by sulci, which are interconnected by small crests that form small pits. Ridges and sulci radiates from an area in which pits are predominant near the corner below the ascending process representing the ossification center. The clavicular blade is medially thinner on its surface of articulation with the interclavicle while the lateral margin of the clavicle is thicker and rounded forming a low wedge-shaped anterolateral counterfort. A small posterior laminar buttress (pectinate fringe) is present at the base of the ascending process (Figures 9C-D), but in Rastosuchus hammeri gen. et sp. nov. this fringe is restricted to the ventral half of the ascending process and does not reach the tip of the process as in Trimerorhachis insignis (Pawley, 2007). The ascending process is 'rod-like' distally, sloped $40^{\circ}$ to $45^{\circ}$ backward, slightly sigmoid in anterior and posterior views (Figures 9E-F). The left cleithrum of UFRGS-PV0356-P (Figures 9G-H) is a robust, elongated bone slightly expanded dorsoposteriorly, straight medially. It possesses an almost cylindrical rod-like cleithral shaft in which its ventral end is broken and was lost. The dorsal cleithral process is a dorsoposterior expansion turned $35^{\circ}$ posteriorly from the cleithral shaft that covers the dorsalmost surface of the scapulocoracoid. Although bad preserved, is possible to identify the scapular flange of the cleithral shaft in both medial and lateral views, by a very smooth lateral cleithral ridge. The scapular flange is as straight as the anterodorsal chamfer of the scapular blade. The left scapulocoracoid of UFRGS-PV-0356-P (Figures 9I-L) is $75 \mathrm{~mm}$ height and $37 \mathrm{~mm}$ long. The scapular blade is almost complete, but the coracoid portion is badly preserved, and a small part of it was reconstructed with plaster. In lateral view, the scapular blade presents straight anterodorsal chamfer with small short grooves for the cleithrum attachment. The posterior scapular border presents a medial supraglenoid buttress and a lateral supraglenoid ridge on the border of a shallow supraglenoid fossa. Within the supraglenoid fossa, is the supraglenoid foramen. The morphology of the supraglenoid region is very similar to that of South African rhinesuchid (Pawley \& Warren, 2004). It is distinct from the supraglenoid furrow of Australerpeton cosgriffi (Dias \& Schultz, 2003a) in which the lateral supraglenoid ridge is similar in size, comparatively, to the medial supraglenoid buttress. The coracoid, despite the incomplete preservation, presents the coracoid foramen anteriorly, but very close to the glenoid cavity. In medial view, the scapulocoracoid presents a well-developed and almost 


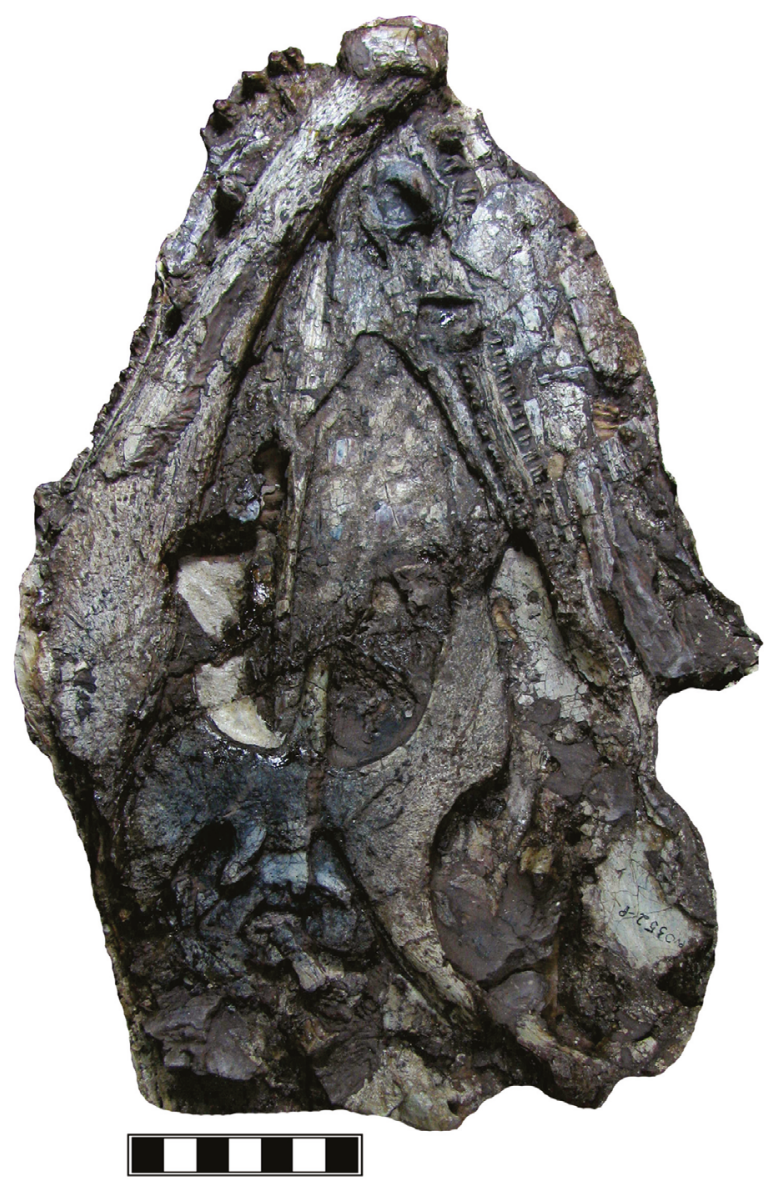

Figure 12. Skull referred to Rastosuchus hammeri gen. et sp. nov., photograph of the specimen UFRGS-PV-0352-P, preserved in ventral view. Lower jaw strongly attached. Scale bar $=7 \mathrm{~cm}$.

vertical scapular torus, a medial bone buttress. Anteriorly to the scapular torus, a subscapular fossa is present, which in reality is a thin portion of the scapulocoracoid blade. Due to the preservation, its foramina are not clearly visible in medial view.

Hind limb (Figure 10). The left femur of UFRGS-PV0356-P was previously mentioned by Dias \& Schultz (2003a) with a different collection number (UFRGS-PV-036-P, a typing error). This left femur (UFRGS-PV-0356-P) possesses a robust, well-ossified, and slightly anteriorly placed internal trochanter with a protuberant detached finger-like proximal projection (Figures 10A-E), or simply a finger-like internal trochanter that is directed in an angle of approximately 35 $40^{\circ}$ regarding the femur axis. The ventral face of the internal trochanter continues medially, forming a conspicuous adductor blade (Figure 10D). The region of the fourth trochanter is present in the end of adductor blade (Figure 10D). The head of the femur is wide and rounded with the dorsoposterior sulcus evident, and also presents a posteroventral projection that is ventral to the dorsoposterior sulcus which continues into a rounded posterior intertrochanteric ridge becoming acute distally near the fourth trochanter (Figures 10A, D). At the level of the fourth trochanter, the posterior intertrochanteric

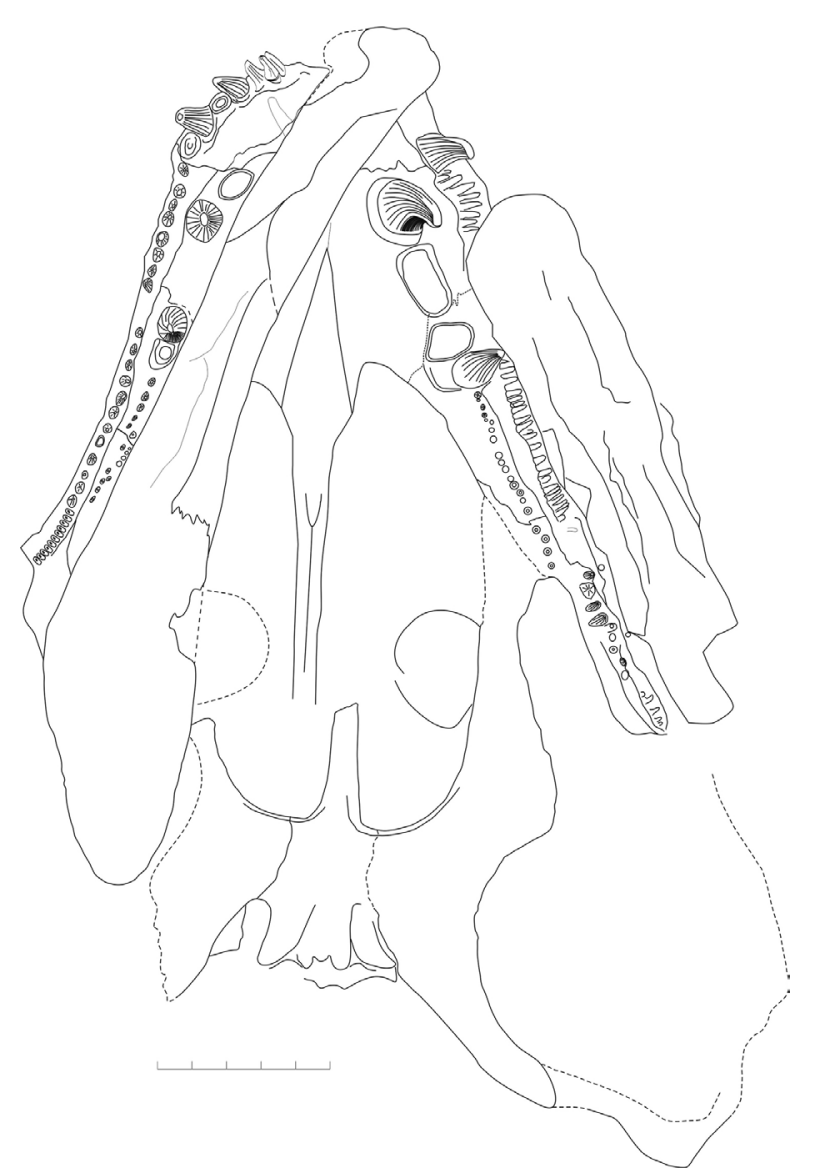

Figure 13. Interpretation drawing of the skull UFRGS-PV-0352-P referred to Rastosuchus hammeri gen. et sp. nov. Scale bar $=5 \mathrm{~cm}$.

ridge joins the adductor blade forming a single adductor crest running toward the femur distal extremity (Figure 10D). The distal extremity of the femur presents two condyles (tibial condyle partially broken) with a broad shallow ventral concave popliteal area (Figures 10C, D, F) and a pronounced fibular condyle ventral portion. Between the condyles a shallow dorsal intercondylar fossa (fossa tendinalis), not as shallow as in Australerpeton cosgriffi (Dias \& Schultz, 2003a; Eltink \& Langer 2014), been slightly deeper (Figures 10B, F). A smooth fibular fossa is present in the distal posterior surface (Figures 10D, F). The left tibia (Figures 10G, J) is expanded proximally and rod-like distally. In dorsal (anterior) view it presents a small cnemial cristae (crest), but due to bad preservation, other features are hard to detect, including those of the posterior (ventral) view. The left fibula (Figure 10H, I) presents straight lateral border and a strongly concave medial border, and distally is expanded and flattened. In posterior (ventral) view it presents a long posterior fibular ridge and a pronounced medial fibular sulcus on its distal extremity. In anterior (dorsal) view the fibular extensor cristae and the anterior fibular cristae are not conspicuous. Four autopodial elements that seems to be metatarsals are present in the 


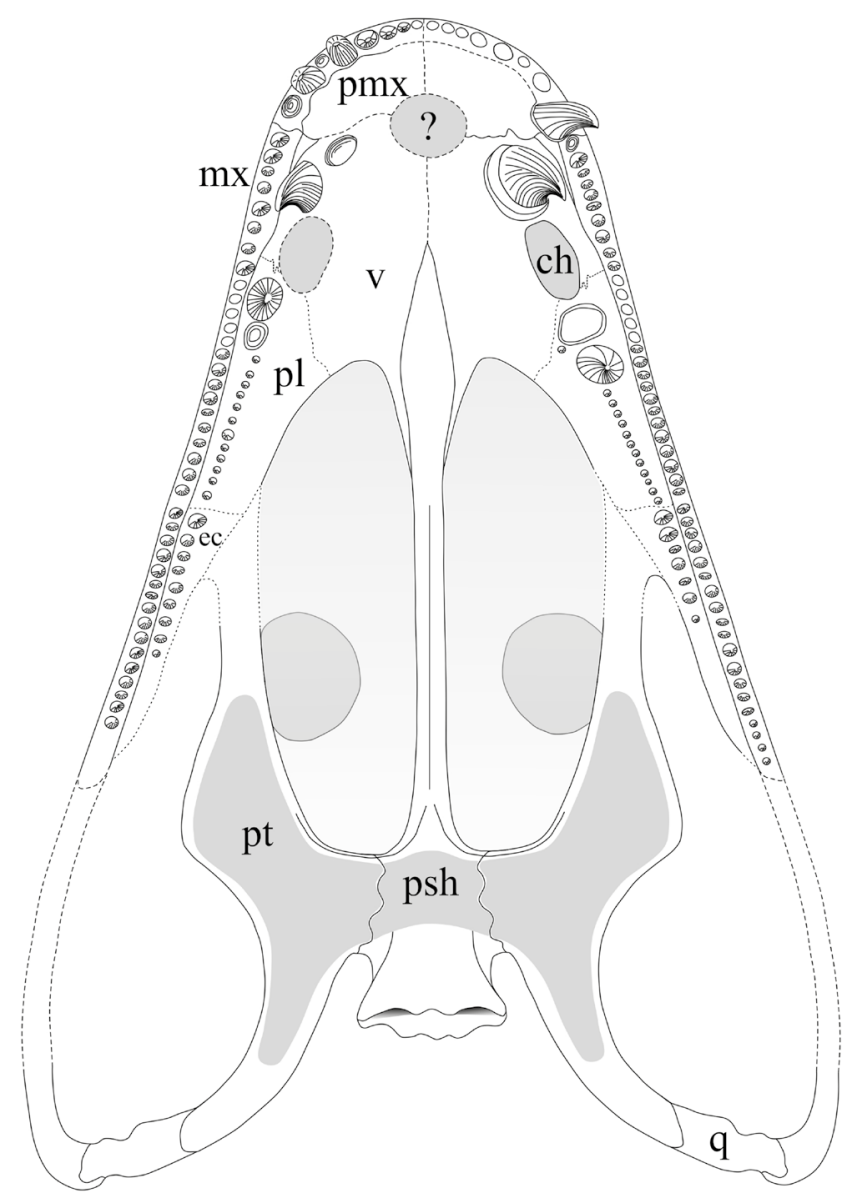

Figure 14. Reconstruction drawing of the palatal view based on the skull UFRGS-PV-0352-P referred to Rastosuchus hammeri gen. et sp. nov. Abbreviations: ch, choana; ec, ectopterygoid; mx, maxilar; pl, palatine; pmx, premaxilar; $\mathbf{p s h}$, parasphenoid; pt, pterygoid; $\mathbf{q}$, quadrate; $\mathbf{v}$, vomer. Gray area on the parasphenoid and pterygoid represents field of denticles (shagreen).

material (Figure 10L-S), corresponding to $1 / 3$ of femur and $1 / 2$ of tibia and fibula in length.

Referred material. Skull (Figures 11-15). As already mentioned, the skull UFRGS-PV-0352-P is the short-snouted temnospondyl presented by Barberena \& Dias (1998) without a formal taxonomic assignation. This skull is here referred to Rastosuchus hammeri gen. et sp. nov. A CT-Scan was performed on the skull UFRGS-PV-0352-P in order to find out diagnostic features such as the coronoid dentition on its attached mandible (Sipp et al., 2018). In spite of difficulties related to the size of the specimen and resolution requirements, after virtually isolate the right mandible using the software Avizo 7.1, two parallel tooth rows were found on the dorsomedial portion of the mandible seen as two cristae in the CT-scan images, just in the region that corresponds to the coronoid bone (Figure 11A). These tooth rows run forward to the intercoronoid position where they are slightly close to each other showing a more intense taphonomical compression between dentary and intercoronoid. On the position of the precoronoid the presence of the tooth row is more difficult to identify due to fractures, distortion and superposition with the

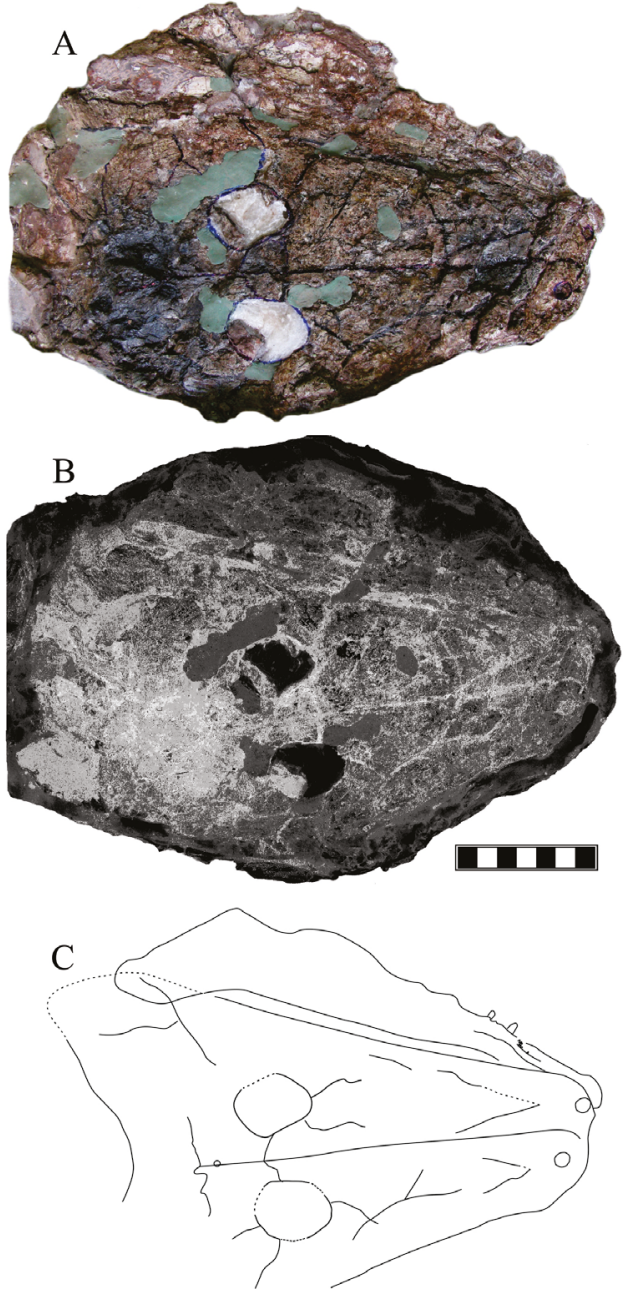

Figure 15. Skull referred to Rastosuchus hammeri gen. et sp. nov. in dorsal view (UFRGS-PV-0352-P). A, photograph of the specimen in dorsal under visible light. B, photograph under ultraviolet light. $\mathbf{C}$, drawing of the most significant lines. Scale bar $=7 \mathrm{~cm}$.

premaxillary dentition. The CT-Scan image of the UFRGSPV-0352-P right lower jaw (Figure 11A) set side by side and aligned to a complete mandible photomontage based on the specimens UFRGS-PV-0235-P and UFRGS-PV-0350a-P (Figure 11B) and both aligned with the specimen UFRGSPV-0357-P (Figure 11C) show that the dentary and coronoid series tooth rows are present on the specimen UFRGS-PV0352-P. This evidence gives the confidence to refer this skull to the species Rastosuchus hammeri gen. et sp. nov. The CT-Scan also revealed an intense taphonomic flattening of the specimen, as seen on Figure 11 and CT-scan images (supplementary material). The skull UFRGS-PV-0352-P has $28 \mathrm{~cm}$ long and at least $20 \mathrm{~cm}$ wide (measures taken directly on the specimen) and is badly preserved (Figures 12-13). Considering the taphonomical distortions, a proposal reconstruction in order to correct it is present (Figure 14). The right mandible is attached to the skull covering the anterior palatal region and right palatal margin. This mandible is badly preserved precluding a precise visualization of sutures. The skull UFRGS-PV-0352-P here referred to Rastosuchus hammeri gen. et sp. nov. was initially prepared in palatal view 
(Barberena \& Dias, 1998). In a recent preparation effort, the skull roof was exposed, but due to its bad preservation and fragility, photos of the dorsal view were taken, and then the skull roof was covered again with plasticine to protect the integrity of the specimen. These photos of the dorsal view provide information on the general skull outline, position of orbits, narial openings, and some sutures. Unfortunately, most of bone sutures were very unclear (Figure 15).

Ventral view of the skull UFRGS-PV-0352-P (Figures 1214). The left palatal margin is comparatively better preserved, and palatal tusks, left choana and marginal dentition are clear. The right posterior region of the skull is missing, and an oblique fracture crosses it at the level of the interpterygoid vacuity. Pterygoid and parasphenoid are preserved at the level of the braincase. The specimen is dorsoventrally compressed, so that the occiput is partially visible only in ventral view (Figures 12-13). The premaxilla is partially obstructed by the right mandible, so that only four teeth can be surely observed, but presumably more were present. Posterior premaxillary teeth are larger than anterior ones, and also larger than those of the maxillary. The suture between premaxilla and maxilla is at the level of the anterior basis of the vomerine tusk. The anterior palatal fossa is not visible as it is covered by the attached right lower jaw. According to Barberena \& Dias (1998), the maxillary dentition would comprise 24-28 teeth. In the present reassessment of UFRGS-PV-0352-P, we estimate, based on teeth sizes and maxillary extension, the presence of 46 teeth in the right side of the skull and 43 teeth in the left maxillary. The vomers are also partially covered by the right lower jaw, but left vomer is better exposed. The choana is oval in shape and bordered by the vomer medially and anteriorly. The lateral process of the vomer meets the anterolateral process of palatine to form a suture that seems to exclude the maxilla from the lateral margin of the choana. There is no evidence of teeth in the medial margins of the choanae. The vomer is a large sheet of bone that forms the anterior margins of the interpterygoid vacuities, and does not contact the pterygoid neither the ectopterygoid, so the palatine participates on the lateral margin of each interpterygoid vacuity. A single well-developed vomerine tusk is present on each side, and anteriorly placed in relation to each choana. The left vomerine tusk is slightly bigger than the right one, probably due to distinct development stages before and after substitution. No vomerine denticles can be observed but is not possible to confirm if this is due to its bad preservation or absence as already noted by Barberena \& Dias (1998). The posterolateral ramus of the vomer is at the level of the palatine tusk on the left side and is behind the level of the palatine tusk on the right side. Each palatine tusk is accompanied by a shallow empty concavity of a fallen tooth, backward on the right palatine tusk, and forward on the left palatine tusk. These differences can be attributed to alternated dental substitution on each side of the palatine. The palatine bears a single welldeveloped anterior tusk, which is followed backward by approximately 10 to 11 palatine teeth. The suture between palatine and ectopterygoid is transversal and straight and does not extend posteriorly to the anterior ectopterygoid teeth, so the ectopterygoid does not participate on the interpterygoid vacuity margin. A tooth row of about 17 to 20 teeth is present in the ectopterygoid as already mentioned by Barberena \& Dias (1998). Tusks are absent in the ectopterygoid. The interpterygoid vacuity is three times longer than wide and is separated from the subtemporal fenestra only by the palatine ramus of the pterygoid. In ventral view, the lateral margin of the palatine ramus of the pterygoid bears a flange, which enters to the subtemporal fenestra. The subtemporal fenestra is remarkable elongated, covering half of the total skull length with the anterior portion quite pointed. The anterolateral margin of the subtemporal fenestra is partially composed by the ectopterygoid and maxilla. The pterygoid and exoccipitals do not present a clear contact preserved, and there is no evidence of a sulcus behind the pterygoid-parasphenoid suture. The cultriform process of the parasphenoid is narrow (width is less than $10 \%$ of its length) with lateral margins meeting to form a midline ventral keel. Anteriorly, the cultriform process presents a spear tip-like enlargement in its vomerian portion. The pterygoid and parasphenoid bears a linear groove at the posterior interpterygoid vacuity margin for the attachment of the palatal mucous membrane that covers the interpterygoid vacuity. The parasphenoid plate presents an elongated transversal crista muscularis transversal that composes well-marked anterior borders of two clear depressions on its ventral surface, the parasphenoid pockets (Figure 14), as already pointed out by Barberena \& Dias (1998). The parasphenoid and pterygoids are well sutured in a broad contact along more than half of the lateral margins of the parasphenoid plate. The parasphenoid plate is subrectangular with small posterolateral expansions that can be considered as lateral wings. It bears an extensive denticle field (shagreen) forming an arched transverse belt. The quadrate ramus of the pterygoid is untwisted, forming a near horizontal plate that is almost continuous with the plane of the pterygoid corpus and palatine ramus. The pterygoids also bear shagreen of denticles. Barberena \& Dias (1998) related this absence of denticles to the bad preservation, but after a cleaning with acetone, and careful observation, we conclude that denticles are present. The quadratojugal and quadrate presents a sulcus separating an overhanging quadratojugal. The two occipital condyles are formed by the exoccipitals, apparently without a basioccipital contribution, and anteriorly placed in relation to the quadrate condyle placed.

Dorsal view of the skull UFRGS-PV-0352 (Figures $15 \mathrm{~A}-\mathrm{C}$ ). The dorsal view preparation revealed a damaged skull (Figure 15A). Photos under ultraviolet light was taken as an effort to find sutures and bone limits (Figure 15B), but unfortunately, bad preservation is awful, so the presented drawing is just to illustrate it (Figure 15C). Even so, it was possible to observe some features. The skull UFRGS-PV0352-P is estimated 1.2 times longer than wide, and the estimated length of the skull table is around $45 \%$ of its width so the orbits are placed slightly posteriorly to the mid length of the skull. The interorbital distance is less than $50 \%$ of the width of the skull at the mid orbital level. The preorbital region presents a tapering format, with apparently more than 
twice the length of posterior skull table. The narial openings are almost circular, seems to be dorsally oriented, and as close to each other as the orbits. There is no evidence that mandibular tusks penetrated the tip of the snout. The snout margins are continuous and not anteriorly expanded. The dermal bone ornamentation is composed of ridges enclosing pits, which become more elongated (furrows) in some elongated bones, a pattern observed also on the lower jaw and clavicle of Rastosuchus hammeri gen. et sp. nov. (UFRGSPV-0350-P; UFRGS-PV0357-P). The orbits are rounded, and its surrounding bones seem to be flat, so the orbital margins are at the same level of the skull roof (both characters shared with Rhinesuchinae, Eltink et al., 2019). Orbits are placed medially so it is possible to estimate that they are framed by wide jugals even if these bones are not clearly preserved. The orbits are almost halfway of the estimated total skull length. The interorbital distance is small, being around $20 \%$ of the skull estimated width at the level of the orbits. The preorbital region is also flat (a character shared with all Rhinesuchidae, Eltink et al., 2019). The frontal-parietal suture is anterior to level of the posterior orbital rim.

\section{DISCUSSION}

The systematic assignment of Rastosuchus hammeri gen et sp. nov. to the Rhinesuchidae was firstly proposed by Barberena et al. $(1980,1985 \mathrm{a}, \mathrm{b})$ when the species name was first mentioned without a formal description, and by Barberena \& Dias (1998) when "the Serra do Cadeado short-snouted amphibian" was preliminarily presented. Its position within Rhinesuchidae was confirmed in Eltink et al. (2016).

Once Rastosuchus hammeri gen. et sp. nov. is based mainly on mandibular and postcranial material, and the skull is a referred specimen, mandibular features will be discussed first, and cranial features will be discussed later.

Rastosuchus hammeri gen. et sp. nov. presents the posterior meckelian foramen bordered by prearticular, postsplenial and angular, which is considered a plesiomorphic condition among temnospondyls. Marsicano et al. (2017, fig. 3) illustrated similar condition for 'Rhinesuchus beaufortensis' and also considered this taxon a junior synonym of Rhinesuchus whaitsi. According to Watson (1962) the South African rhinesuchid Rhineceps nyasaensis presents the posterior meckelian foramen bordered exclusively by the prearticular and postsplenial, but an illustration by Schoch \& Milner (2000) depicting a mandible attributed to Rhineceps nyasaensis does not show the contact between postsplenial and angular (if behind or posterior to the foramen). Broom (1930) illustrated a mandibular element from the South African rhinesuchid Uranocentrodon as presenting the angular participating in the border of the posterior meckelian foramen, but this assertion seems to be uncertain. This feature is also observed in Australerpeton cosgriffi as seen on the specimen LPRP/USP-0011 presented by Eltink \& Langer (2014), and in UFRGS-PV-0224-P, in both the posterior meckelian foramen is bordered by prearticular, postsplenial and angular as in $R$. hammeri gen. et sp. nov.
Rastosuchus hammeri gen. et sp. nov. presents welldeveloped conical teeth on all three coronoid bones (rather than denticles) that is a remarkable feature of all the mandibular samples. Schoch \& Milner (2000) pointed that coronoids are dentigerous in primitive tetrapods, in basal temnospondyls, and several lineages retained this condition, such as Sclerocephalus (Schoch, 2003). However, most rhinesuchids (Rhineceps nyasaensis, and 'Rhinesuchus beaufortensis' for example) present small denticles rather than conical teeth on the coronoid series, a feature that distinguishes Rastosuchus hammeri gen. et sp. nov. from the known rhinesuchids. Within Stereospondyli, the presence of dentition all over the coronoid series is restricted to Dvinosaurus, Almasaurus (Schoch \& Milner, 2000) and Plagiosauridae (Yates \& Warren, 2000). Coronoid dentition is absent in Australerpeton cosgriff (Eltink \& Langer, 2014; Eltink et al., 2016).

The presence of arcadian groove is a Stereospondylomorpha character according to Yates \& Warren (2000). The absence of a hamate process in Rastosuchus hammeri gen. et sp. nov. is a plesiomorphic condition found in many temnospondyls, including rhinesuchids. The derived condition is later achieved in some advanced stereospondyls such as mastodonsaurids (Schoch, 1999; Schoch \& Milner, 2000). On the other hand, the anterior portion of the "L-shaped" glenoid fossa is very close to the hamate process described by Damiani et al. (2001) for Watsonisuchus, however in Rastosuchus hammeri gen. et sp. nov. it was part of the articulation surface instead an area of muscle insertion as in Mastodonsaurus giganteus (Schoch, 1999). The sample described by Damiani et al. (2001) also differs from R. hammeri gen. et sp. nov. in having a precondylar process, a more convex crista arcuata and a much smaller chorda tympanic foramen.

Regarding to the femur, Pawley (2007) described a rodlike internal trochanter for Trimerorhachis insignis. Pawley $(2006,2007)$ pointed that a rod-like internal trochanter is less developed in young individuals and probably more developed in mature animals. Pawley (2007) also suggests that these structures can result in distinct anatomies as consequences of heterochrony, especially paedomorphosis. Following this point of view, the known femora of Australerpeton cosgriff, UFRGS-PV-0319-P (Dias \& Schultz, 2003a) and LPRP/USP0011 (Eltink \& Langer, 2014), seems to be paedomorphic in relation to the femur of Rastosuchus hammeri gen. et sp. nov. once in $A$. cosgriffi the internal trochanter and fossae are similar to that of younger Trimerorhachis insignis. This corroborates that $A$. cosgriffi had a mostly aquatic piscivorous mode-of-life, as presumed by Dias \& Schultz (2003a,b) and Eltink \& Langer (2014). On the other hand, Rastosuchus hammeri gen. et sp. nov. femur probably belongs to an adult individual, showing a strong well-ossified finger-like internal trochanter proximally separated from the femur head by a trough-like space. Even this condition is similar to that of Trimerorhachis insignis, the tip of the internal trochanter being well-ossified indicates a non-paedomorfic condition, also indicated by a more developed posterior intertrochanteric ridge, and slightly deeper intertrochanteric, popliteal and 
intercondylar fossae, which could indicate a more terrestrial habit for $R$. hammeri gen. et sp. nov. than Australerpeton cosgriffi.

Australerpeton cosgriffi and Rastosuchus hammeri gen. et sp. nov. shares, several features such as, a shallow trough behind the glenoid socket in the PGA, the articulation between adjacent intercentra, and the lateral surfaces of the cultriform process of the parasphenoid meeting to form a midline ventral keel, pockets on the parasphenoid and more. On the other hand, the elongated mandible of $A$. cosgriffi is distinct from the short $R$. hammeri gen. et sp. nov. mandibles, and the presence of teeth in all three coronoids is not present in $A$. cosgriffi. Moreover, $R$. hammeri gen. et sp. nov. presents a posterolateral flange on the palatine ramus of the pterygoid that is absent in A. cosgriffi.

Jupp \& Warren (1986) considered the presence of an enlarged anterior meckelian foramen a synapomorphy of Rhinesuchidae and Uranocentrodontidae. Rastosuchus hammeri gen. et sp. nov. also presents this feature, suggesting a close relationship with these taxa. Other features observed in $R$. hammeri gen. et sp. nov. are shared with some Stereospondylomorpha taxa. For instance, the palatine ramus of the pterygoid bearing a posterolateral flange which is also present in several taxa such as Laccosaurus watsoni, Rhinesuchoides tenuiceps, Broomistega putterilli, Lapillopsis nana, Konzhukovia vetusta, among others.

A comparison with other Paleozoic short-snouted temnospondyls of the Paraná Basin allows distinguishing Rastosuchus hammeri gen. et sp. nov. from them. In Arachana nigra, a short-snouted temnospondyl from the PermianTriassic of Uruguay (Piñeiro et al., 2012), the palatine ramus of the pterygoid presents a long narrow sheet that sutures with the vomer, excluding the palatine from the margin of the interpterygoid vacuity. In Rastosuchus hammeri gen. et sp. nov. (UFRGS-PV-0352-P), the palatine participates on the interpterygoid vacuity margin, so the pterygoid does not contact the vomer. The palatine tusk of $A$. nigra is reduced while in $R$. hammeri gen. et sp. nov. this tusk is welldeveloped. Furthermore, in A. nigra the portion of the palate anterior to the interpterygoid vacuity is shorter than in $R$. hammeri gen. et sp. nov. The vomer of $A$. nigra presents teeth bordering the choana, which is not observed in $R$. hammeri gen. et sp. nov.

Parapytanga catarinensis Strapasson et al., 2015 is another presumed short-snouted temnospondyl from the Rio do Rasto Formation found at the Serra do Espigão area in the State of Santa Catarina. Following the original illustration (Strapasson et al., 2015 fig. 3), the posterior end of the dentary presents a couple of process, one dorsal process that enters the surangular, and a ventral process that enters between surangular and angular. This creates a zigzag-shaped posterior suture for the dentary in Parapytanga catarinensis. On the other hand, Rastosuchus hammeri gen. et sp. nov. present a single posterior dentary process that sutures only with the surangular as shown on Figure 6A. However, a verification on the holotype of $P$. catarinensis (UFRGS-PV0355-P) revel that the anterior region of the angular presents a series of fractures that hinder its suture with the dentary, so the condition presented by Strapasson et al. (2015) is difficult to verify. Even so, using inclined illumination is possible to verify a more conventional suture between dentary, angular and surangular in Parapytanga catarinensis without the ventral posterior process of the dentary. In Rastosuchus hammeri gen. et sp. nov. the ventral region of the mandible presents small pits and short ridges (Figures $2 \mathrm{~B}-\mathrm{C}, \mathrm{E}, 5 \mathrm{~A}, \mathrm{D}$ ) while $P$. catarinensis presents a much thicker ventral region with a series of elongated grooves and ridges, as seen in the postsplenial (Strapasson et al., 2015 fig. 3). This condition is very similar to that found on the specimen UFRGS-PV0348-P referred as an incomplete mandible of Australerpeton cosgriffi by Eltink et al. (2016). The parasphenoid-pterygoid suture of $P$. catarinensis seems to be more robust and similar to that observed in A. cosgriffi specimens than in R. hammeri gen. et sp. nov. skull (UFRGS-PV-0352-P). Finally, the distal portion of the femur of $P$. catarinensis is as slender as in $A$. cosgrifffi, and distinct from the much robust femur of $R$. hammeri gen. et sp. nov. even considering femura of similar sizes. The scapula assigned to $R$. hammeri gen. et $\mathrm{sp}$. nov. presents a supraglenoid angle slightly more open than $P$. catarinensis while the coracoid blade seems to be anteriorly wider than in $R$. hammeri gen. et sp. nov. As a consequence, these observations indicate that $P$. catarinensis is closer related to $A$. cosgriffi if not a junior synonymous, notwithstanding it needs a more careful verification.

The skull outline of Konzhukovia sangabrielensis Pacheco et al., 2016, a Konzhukoviidae with an expanded snout tip and lateral margins concave before the tip, is clearly different from the rounded snout with divergent lateral margins of the skull referred to Rastosuchus hammeri gen. et sp. nov. The vomer of $K$. sangabrielensis presents a parachoanal dentition which is absent in $R$. hammeri gen. et sp. nov. In addition, based on the mandibles the presumed outline is also rounded with divergent laterals.

It is not clear in Rastosuchus gen. nov. that the palatine ramus of the pterygoid extends anterior to the anteriormost ectopterygoid tooth, but a tentative reconstruction points to this condition. Besides the bad preservation, the palatine ramus of the pterygoid of UFRGS-PV-0352-P seems to not contact the vomer as in Australerpeton cosgriffi and Laccosaurus watsoni, while a very thin projection of the pterygoid contact the vomer in Rhineceps nyasaensis, Rhinesuchus capensis, Rhinesuchus whaitsi, and Uranocentrodorn senekalensis.

It is possible to list some of the features present on Rastosuchus hammeri gen. et sp. nov. and its referred material that allowed us to ascribe it to the Rhinesuchidae, as follows: posterior premaxillary teeth larger than anterior premaxillary and maxillary teeth; posterolateral ramus of the vomer extending posterior to the palatine tusks; and in the mandible, prearticular extending anteriorly, at least as far as the level of the midpoint of the intercoronoid. However, other typical features of rhinesuchids are not observable in the material referred to $R$. hammeri gen. et sp. nov., or depends on unsure interpretation, and may be consequence of its bad preservation or absence of some parts of the specimens, including: the 
tabular horn presents a thin ventrally projecting crest of bone, frequently projecting posterior to the ornamented dorsal component of the horn, prefrontal lateroposteriorly constricted (not preserved); bilobate occipital condyle with reduced basioccipital contribution (badly preserved). Barberena (1998) placed Australerpeton within the Superfamily Rhinesuchoidea erecting the family Australerpetonidae, and Barberena \& Dias (1998) pointed that the short-snouted forms should be more properly assigned to the Rhinesuchidae.

However, Schoch \& Milner (2000) changed the taxonomic assignation of both Australerpeton cosgriffi and the short-snouted specimen UFRGS-PV-0352-P described by Barberena \& Dias (1998) here assigned to Rastosuchus hammeri gen. et sp. nov., arguing that both should be stemstereospondyls. Still according to Schoch \& Milner (2000), A. cosgriffi would be ascribed to Archegosauridae (subfamily Platyoposaurinae), whereas UFRGS-PV-0352-P would belong to Melosauridae (subfamily Tryphosuchinae) suggesting that would be a second species of Konzhukovia. In both cases, Schoch \& Milner (2000) did not provide arguments to support their hypothesis, and they present these changes without examining those specimens.

Witzman \& Schoch (2006) performed a phylogenetic analysis using exclusively characters from postcranial skeleton in which Australerpeton appears as the sister taxon of Uranocentrodon plus all stereospondyls higher than Uranocentrodon. A similar phylogenetic position of Australerpeton and Uranocentodon was presented in Schoch et al. (2007). For the sake of accuracy, both descriptions of A. cosgriffi by Barberena (1998) and UFRGS-PV-0352-P by Barberena \& Dias (1998) were faulty in some respects. None of them provided photographs of the specimens, only interpretative drawings. In this context, a detailed review of the entire type series of $A$. cosgriffi was presented on Eltink et al. (2016).

The family Rhinesuchidae has been recovered as a monophyletic group in several phylogenetic analyses such as Yates \& Warren (2000), Ruta et al. (2003), Pawley (2006), Eltink \& Langer (2014), Eltink et al. (2016) and Marsicano et al. (2017). Rastosuchus hammeri gen. et sp. nov. is here considered as a member of the Rhinesuchidae based on the phylogenetic analysis presented by Eltink et al. (2016), in which this taxon is referred as "Serra do Cadeado shortsnouted". Within this group, South American rhinesuchids (Australerpeton cosgriffi and Rastosuchus hammeri gen. et sp. nov.) are probably sister-taxa as recovered by Eltink et al. (2016). Conversely, in Marsicano et al. (2017) Australerpeton was recovered as sister-group of all other South African rhinesuchids in a different tree topology. So, it is quite probable that South African rhinesuchids such as Uranocentrodon, Rhinesuchus and Rhineceps, have a close relationship with Australerpeton and Rastosuchus gen. nov., but this hypothesis needs to be carefully tested under a phylogenetic context.

Regarding to the specimen UFRGS-PV-0352-P here referred to Rastosuchus hammeri gen. et sp. nov., it is important to point out that its overall appearance, as drawn by Barberena \& Dias (1998), indeed resembles that of Konzhukovia vetusta, specially its quadrate condyle is delicate in comparison with that of other stereospondyls, and similar to the quadrate of stem-stereospondyls; the shape of the subtemporal fossa of UFRGS-PV-0352-P, which is elongated and narrow anteriorly is slightly similar to that of Konzhukovia (and archegosauroids in general). However, even if considered some taphonomic distortions, the subtemporal fenestra of UFRGS-PV-0352-P is much longer corresponding to half of skull lenght (Figures 12-14).

Gubin (1997) provided a phylogenetic assessment of archegosauroids, and in agreement with Milner (1989, 1990), considered Archegosauroidea as the sister group of Stereospondyli. This was further corroborated by Schoch \& Milner (2000) and Yates \& Warren (2000). According to Gubin (1997, figs. 10, node 12), rhinesuchids and most stereospondyls share several characters that distinguish them from Archegosauroidea. Most derived stereospondyl and rhinesuchid characters listed by Gubin (1997) are present in UFRGS-PV-0352-P, including: (i) a parabolic snout, becoming wider posteriorly, whereas in archegosauroids the snout is straight toward its entire length; (ii) a parasphenoid flat with a relatively long suture with the pterygoid; (iii) the palatine forms part of the border of the interpterygoid vacuity; (iv) a shagreen field is present in the parasphenoid.

According to Yates \& Warren (2000) two of the above cited characters $(2,3)$ are considered unambiguous synapomorphies of Stereospondyli. Still according to Yates \& Warren (2000) the suturing of the parasphenoid and pterygoid is a distinctive character that separates stereospondyls from all other temnospondyls. Finally, the snout margins in UFRGSPV-0352-P are continually convergent towards the tip, with no observable sign of constriction behind the narial level such as in some archegosauroids like Konzhukovia vetusta and Melosaurus uralensis. There is no pre-narial extension of the premaxilla, which seems to be shorter than the narial opening, so that the tip is short, and the snout outline is slightly rounded. Consequently, these features of Rastosuchus hammeri gen. et sp. nov. (UFRGS-PV-0352-P) sustain the hypothesis that it is a rhinesuchid stereospondyl and not an archegosauroid as stated by Schoch \& Milner (2000).

Most of the features presented and discussed here were included in the phylogenetic analysis presented by Eltink et al. (2016) as "Serra do Cadeado short-snouted", in which Rastosuchus hammeri gen. et sp. nov. nested as sister taxon of Australerpeton cosgriffi within the Rhinesuchidae.

\section{ACKNOWLEDGEMENTS}

The authors dedicate this work to M. C. Barberena † who organized the expeditions to collect and started the study of temnospondyls in the Paraná Basin. We also thank some of the field trip members U. Faccini, E. Lavina, S.A.K. Azevedo and V. Costa $\uparrow$, the late for the careful preparation of the specimens. We also thank E. Latimer, R. Damiani and C. Marsicano for gently sending us drawings, photos and for discussion regarding South African material. E.V. Dias and C.L. Schultz 
make a special reference to T. Kroeff for his first attempt to describe the mandibular materials of Rastosuchus gen. nov., G.S. Sipp for the CT-Scan images treatment and interpretation, and M.I. Preza for help on the map drawing. We would like to thank the Conselho Nacional de Desenvolvimento Científico e Tecnológico for the financial support: EVD (CNPq 150469/2003-9), CLS (CNPq 307711/2017-0) and SDS (CNPq 308223/2019-5).

\section{REFERENCES}

Alessandretti, L.; Machado, R.; Warren, L.V.; Assine, M.L. \& Lana, C. 2016. From source-to-sink: the Late Permian SW Gondwana paleogeography and sedimentar dispersion unraveled by a multiproxy analysis. Journal of South American Earth Sciences, 70:368-382. doi:10.1016/j.jsames.2016.06.007

Alessandretti, L.; Warren, L.V.; Machado, R.; Novello, V.F. \& Sayeg, I.J. 2015. Septarian carbonate concretions in the Permian Rio do Rasto Formation: birth, growth and implications for the early diagenetic history of southwestern Gondwana succession. Sedimentary Geology, 326:1-15. doi:10.1016/j. sedgeo.2015.06.007

Araújo, D.C. 1984. Sistemática e taxonomia de pareiassauros: histórico e perspectivas atuais. Pesquisas, 16:227-249.

Azevedo, K.L.; Vega, C.S. \& Soares, M.B. 2017. A new specimen of Australerpeton cosgriffi Barberena, 1998 (Stereospondyli: Rhinesuchidae) from the Middle/Upper Permian Rio do Rasto Formation, Paraná Basin, Brazil. Revista Brasileira de Paleontologia, 20:333-344. doi:10.4072/rbp.2017.3.05

Barberena, M.C. 1998. Australerpeton cosgriffi n.g., n.sp., a Late Permian Rhinesuchoid amphibian from Brazil. Anais da Academia Brasileira de Ciências, 70:125-137.

Barberena, M.C. \& Araújo, D.C. 1975. Tetrápodos fósiles de Sudamérica y deriva continental. In: CONGRESO ARGENTINO DE PALEONTOLOGIA Y BIOESTRATIGRAFIA, 1, 1975. Actas, Tucumán, p. 497-504.

Barberena, M.C.; Araújo, D.C. \& Lavina, E.L. 1985a. Late Permian and Triassic tetrapods of Southern Brazil. National Geographic Research, 1:5-20.

Barberena, M.C.; Araújo, D.C.; Lavina, E.L. \& Azevedo, S.A.K. 1985b. O estado atual do conhecimento sobre os tetrápodes permianos e triássicos do Brasil meridional. In: Coletânea de Trabalhos Paleontológicos, Rio de Janeiro, MME/DNPM, , p. 21-28 (Série Geologia 27).

Barberena, M.C.; Araújo-Barberena, D.C.; Lavina, E.L. \& Faccini, U.F. 1991. The evidence for close paleofaunistic affinity between South America and Africa, as indicated by Late Permian and Early Triassic Tetrapods. In: INTERNATIONAL GONDWANA SYMPOSIUM, 7, 1991. Proceedings, São Paulo, p. 455-466.

Barberena, M.C.; Correia, N.R. \& Aumond, J.J. 1980. Contribuição à estratigrafia e bioestratigrafia do Grupo Passa Dois na Serra do Cadeado (Nordeste do Paraná, Brasil). Revista Brasileira de Geociências, 10:268-275.

Barberena, M.C. \& Dias, E.V. 1998. On the presence of a shortsnouted rhinesuchoid amphibian in the Rio do Rasto Formation (Late Permian of Paraná Basin, Brazil). Anais da Academia Brasileira de Ciências, 70:465-468.

Bona, P. \& Desojo, J.B. 2011. Osteology and cranial musculature of Caiman latirostris (Crocodylia: Alligatoridae). Journal of Morphology, 272:780-795. doi:10.1002/jmor.10894
Boos, A.D.S.; Kammerer, C.F.; Schultz, C.L.; Soares, M.B. \& Ilha, A.L.R. 2016. A new dicynodont (Therapsida: Anomodontia) from the Permian of southern Brazil and its implications for bidentalian origins. PLOS ONE, 11:e0155000. doi:10.1371/ journal.pone.0155000

Brochu, C.A. 1999. Phylogenetics, taxonomy, and historical biogeography of Alligatoroidea. Journal of Vertebrate Paleontology, 19:9-100. doi:10.1080/02724634.1999.10011201

Broom, R. 1930. Notes on some Labyrinthodonts in the Transvaal Museum. Annals of the Transvaal Museum, 14:1-10.

Canile, F.M.; Babinski, M. \& Rocha-Campos, A.C. 2016. Evolution of the Carboniferous-Early Cretaceous units of Paraná Basin from provenance studies based on $\mathrm{U}-\mathrm{Pb}$, Hf and $\mathrm{O}$ isotopes from detrital zircons. Gondwana Research, 40:142-169. doi:10.1016/j.gr.2016.08.008

Cisneros, J.C.; Abdala, F.; Atayman-Güven, S.; Rubidge, B.S.; Celâl Sengör, A.M. \& Schultz, C.L. 2012. Carnivorous dinocephalian from the Middle Permian of Brazil and tetrapod dispersal in Pangaea. Proceedings of the National Academy of Sciences of the United States of America, 109:1584-1588. doi:10.1073/ pnas. 1115975109

Cisneros, J.C.; Abdala, F. \& Malabarba, M.C. 2005. Pareiasaurids from the Rio do Rasto Formation, Southern Brazil: biostratigraphic implications for the Permian faunas of the Paraná Basin. Revista Brasileira de Paleontologia, 8:13-24.

Cisneros, J.C.; Abdala, F.; Rubidge, B.S.; Dentzien-Dias, P.C. \& Bueno, A.O. 2011. Dental occlusion in a 260 million-year-old therapsid with saber canines from the Permian of Brazil. Science, 331:1603-1605. doi:10.1126/science.1200305

Cisneros, J.C.; Marsicano, C.; Angielczyk, K.D.; Smith, R.M.H.; Richter, M.; Frösbisch, J.; Kammerer, C.F. \& Sadleir, R.W. 2015. New Permian fauna from tropical Gondwana. Nature Communications, 6:8676. doi:10.1038/ncomms9676

Cox, C.B. \& Hutchinson, P. 1991. Fishes and amphibians from the Late Permian Pedra de Fogo Formation of Northern Brazil. Palaeontology, 34:561-573.

Daemon, R.F.; Casaletti, P.L. \& Ciguel, J.H.G. 1996. Biopaleogeografia da Bacia do Paraná. In: SIMPÓSIO SUL AMERICANO DO SILURO-DEVONIANO: ESTRATIGRAFIA E PALEONTOLOGIA, 1, 1996. Anais, Ponta Grossa, p. 55-100.

Damiani, R.J. 2001. A systematic revision and phylogenetic analysis of Triassic mastodonsauroids (Temnospondyli: Stereospondyli). Zoological Journal of Linnean Society, 133:379-482. doi:10.1006/zjls.2001.0304

Damiani, R.J. 2004. Temnospondyls from the Beaufort Group (Karoo Basin) of South Africa and their biostratigraphy. Gondwana Research, 7:165-173. doi:10.1016/S1342-937X(05)70315-4

Damiani, R.J.; Neveling, J. \& Hancox, P.J. 2001. First record of a mastodonsaurid (Temnospondyli, Stereospondyli) from the Early Triassic Lystrosaurus Assemblage Zone (Karoo Basin) of South Africa. Neues Jahrbuch für Geologie und Paläontologie Abhandlungen, 221:133-144. doi:10.1127/njgpa/221/2001/133

Damiani, R.J. \& Rubidge, B.S. 2003. A review of the South African temnospondyl amphibian record. Palaeontologia Africana, 39:21-36.

Dentzien-Dias, P.C.; Figueiredo, A.E.Q.; Horn, B.; Cisneros, J.C. \& Schultz, C.L. 2012. Paleobiology of a unique vertebrate coprolite concentration form Rio do Rasto Formation (Middle/Upper Permian), Paraná Basin, Brazil. Journal of South American Earth Sciences, 40:53-62. doi:10.1016/j.jsames.2012.09.008

Dentzien-Dias, P.C.; Poinar Jr, G.; Figueiredo, A.E.Q.; Pacheco, A.C.L.; Horn, B.L.D. \& Schultz, C.L. 2013. Tapeworm eggs in 
a 270 Million-year-old shark coprolite. PLoS ONE, 8:e55007. doi:10.1371/journal.pone.0055007

Dentzien-Dias, P.C.; Poinar Jr., G. \& Francischini, H. 2017. A new actinomycete from a Guadalupian vertebrate coprolite from Brazil. Historical Biology, 29:770-776. doi:10.1080/0891296 3.2016.1241247

Dias, E.V. 2012. A new deep-bodied fossil fish (Actinopterygii) from the Rio do Rasto Formation, Paraná Basin, Brazil. Zootaxa, 3192:1-23. doi:10.11646/zootaxa.3192.1

Dias, E.V. \& Barberena, M.C. 2001. A temnospondyl amphibian from the Rio do Rasto Formation, Upper Permian of Southern Brazil. Anais da Academia Brasileira de Ciências, 73:135-143.

Dias, E.V. \& Kroeff, T. 2002. The lower jaw of the short-snouted from the Rio do Rasto Formation (Upper Permian) Brazil. Porto Alegre, Sociedade Brasileira de Paleontologia, p. 40 (Paleontologia em Destaque 40).

Dias, E.V. \& Richter, M. 2002. On the squamation of Australerpeton cosgriffi Barberena, 1998, a temnospondyl amphibian from the upper Permian of Brazil. Anais da Academia Brasileira de Ciências, 74:477-490.

Dias, E.V. \& Schultz, C.L. 2003a. The first paleozoic temnospondyl postcranial skeleton from South America. Revista Brasileira de Paleontologia, 6:29-42.

Dias, E.V. \& Schultz, C.L. 2003b. Paleobiology of the Late Permian temnospondyl amphibian Australerpeton cosgriffi Barberena, 1998, from southern Brazil. Ameghiniana, 40:54R.

Dias-da-Silva, S. 2012. Middle-Late Permian tetrapods from the Rio do Rasto Formation, Southern Brazil: a biostratigraphic reassessment. Lethaia, 45:109-120. doi:10.1111/j.15023931.2011.00263.x

Eltink, E. \& Dias, E.V. 2012 Temnospôndilos do Brasil: uma breve revisão e aspectos paleobiogeográficos. In: V. Gallo; H.M.A. Silva; P.M. Brito \& F.J. Figueiredo (eds.) Paleontologia de Vertebrados: relações entre América do Sul e África, Editora Interciência, p. 69-98.

Eltink, E.; Dias, E.V.; Dias-Da-Silva, S.; Schultz, C.L. \& Langer, M.C. 2016. The cranial morphology of the temnospondyl Australerpeton cosgriffi (Tetrapoda; Stereospondyli) from the Middle-Late Permian of Paraná Basin and the phylogenetic relationships of Rhinesuchidae. Zoological Journal of the Linnean Society, 176:835-860. doi:10.1111/zoj.12339

Eltink, E \& Langer, M.C. 2008. Novos espécimes de temnospôndilos da Serra do Cadeado (nordeste do Paraná). In: SIMPÓSIO BRASILEIRO DE PALEONTOLOGIA DE VERTEBRADOS, 6, 2008. Boletim de resumos, Ribeirão Preto, p. 86-88.

Eltink, E. \& Langer, M.C. 2014. A new specimen of the temnospondyl Australerpeton cosgriffi from the late Permian of Brazil (Rio do Rasto Formation, Paraná Basin): comparative anatomy and phylogenetic relationships. Journal of Vertebrate Paleontology, 34:524-538. doi:10.1080/02724634.2013.826667

Eltink, E.; Schoch, R.R. \& Langer, M.C. 2019. Interrelationships, palaeobiogeography and early evolution of Stereospondylomorpha (Tetrapoda: Temnospondyli). Journal of Iberian Geology, 45:251-267. doi:10.1007/s41513-019-00105-z

Fraas, E. 1889. Die Labyrinthodonten der Schwäbischen Trias. Palaeontolographica, 36:1-158.

Francischini, H.; Dentzien-Dias, P.; Guerra-Sommer, M.; Menegat, R.; Santos, J.O.S.; Manfroi, J. \& Schultz, C.L. 2018. A middle Permian (Rodian) lungfish aestivation burrow from the Rio do
Rasto Formation (Paraná Basin, Brazil) and associated U-Pb dating. Palaios, 33:69-84. doi:10.2110/palo.2017.050

Getmanov, S.N. 1979. The lower jaw structure in Early Triassic labyrinthodonts. Paleontological Journal, 13:222-228.

Gubin, Y.M. 1997. Skull morphology of Archegosaurus decheni Goldfuss (Amphibia, Temnospondyli) from the Early Permian of Germany. Alcheringa, 21:103-121. doi:10.1080/03115519708619178

Holz, M.; França, A.B.; Souza, P.A.; Iannuzzi, R. \& Rohn, R. 2010. A stratigraphic chart of the Late Carboniferous/Permian succession of the eastern border of the Paraná Basin, Brazil, South America. Journal of South American Earth Sciences, 29:381-399. doi:10.1016/j.jsames.2009.04.004

ICS, 2019. International Chronostratigraphic Chart 2019-05. International Commission on Stratigraphy. Available at http:// www.stratigraphy.org/ICSchart/ChronostratChart2019-05.jpg; accessed on $04 / 05 / 2019$.

Jupp, R. \& Warren, A.A. 1986. The mandibles of the Triassic temnospondyl amphibians. Alcheringa, 10:99-124. doi:10.1080/03115518608619164

Langer, M.C. 2000. The first record of dinocephalians in South America: Late Permian (Rio do Rasto Formation) of the Paraná Basin, Brazil. Neues Jahrbuch für Geologie und Paläontologie Abhandlungen, 215:65-95. doi:10.1127/njgpa/215/2000/69

Langer, M.C.; Eltink, E.; Bittencour, J.S. \& Rohn, R. 2008. Serra do Cadeado, PR - Uma janela paleobiológica para o Permiano continental Sul-americano. In: M. Winge; C. Schobbenhaus; C.R.G. Souza; A.C.S. Fernandes; M. Berbert-Born \& E.T. Queiroz (eds.) Sitios Geológicos e Paleontológicos do Brasil, CPRM, p. 433-450.

Langer, M.C. \& Lavina. E.L. 2000. Amniotas do Neopermiano e Eotriássico da Bacia do Paraná - Répteis e "Répteis mamaliformes". In: M. Holz \& L.F. De Ros (eds.) Paleontologia do Rio Grande do Sul, CIGO/UFRGS, p. 210-235.

Laurini, C.R.; Langer, M.C. \& Richter, M. 2009. Chondrichthyan teeth from the Rio do Rasto Formation, Permian of Brasil. Journal of Vertebrate Paleontology, 29:133A.

Lavina, E.L.; Faccini, U.F. \& Ribeiro, H.J.S. 1993. A Formação Pirambóia (Permo-Triássico) no Estado do Rio Grande do Sul. Acta Geologica Leopoldensia, 16:179-197.

Lavina, E.L. \& Scherer, C.M. 2003. Evolução estratigráfica e paleoambiental da sedimentação neopermiana e mesozóica do Rio Grande do Sul: Implicações na construção do arcabouço estratigráfico da Bacia do Paraná. In: ENCONTRO SOBRE A ESTRATIGRAFIA DO RIO GRANDE DO SUL: ESCUDOS E BACIAS, 1, 2003. Anais, Porto Alegre, p. 145-150.

Leonardi, G.; Sedor, F.A. \& Costa, R. 2002. Pegadas de répteis terrestres na Formação Rio do Rasto (Permiano Superior da Bacia do Paraná), Estado do Paraná. Arquivos do Museu Nacional, 60:213-216.

Malabarba, M.C.; Abdala, F.; Weiss, F.E. \& Perez, P.A. 2003. New data on the Late Permian vertebrate fauna of Posto Queimado, Rio do Rasto Formation, Southern Brazil. Revista Brasileira de Paleontologia, 6:49-54.

Marsicano, C.A.; Latimer, E.; Rubidge, B. \& Smith, R.M.H. 2017. The Rhinesuchidae and early history of the Stereospondyli (Amphibia: Temnospondyli) at the end of the Palaeozoic. Zoological Journal of the Linnean Society, 181:357-384. doi:10.1093/zoolinnean/zlw032 
Milani, E.J.; Faccini, U.F.; Scherer, C.M.; Araújo, L.M. \& Cupertino, J.A. 1998. Sequences and stratigraphic hierarchy of the Paraná Basin (Ordoviciano to Cretaceous), southern Brazil. Boletim IG USP, 29:125-173. doi:10.11606/issn.2316-8986.v29i0p125-173

Milani, E.J.; Melo, J.H.G.; Souza, P.A.; Fernandes, L.A. \& França, A.B. 2007. Bacia do Paraná. Boletim de Geociências da Petrobras, 15:265-287.

Milner, A.R. 1989. The relationships of the Eryopoid-grade Temnospondyl Amphibians form the Permian of Europe. Acta Musei Reginaehradecensis S.A.: Scientiae Naturales, 22:131-137.

Milner, A.R. 1990. The radiations of temnospondyl amphibians. In: P.D. Taylor \& G.P. Larwood (eds.) Major evolutionary radiations, Clarendon Press, p. 321-349.

Milner, A.R. 1993. Amphibian-grade tetrapoda. In: M.J. Benton (ed.) The fossil record, Chapman \& Hall, p. 663-677.

Milner, A.R. \& Sequeira, S.E.K. 1994. The temnospondyl amphibians from the Viséan of East Kirkton, West Lothian, Scotland. Transactions of the Royal Society of Edinburgh: Earth Sciences, 83:331-361. doi:10.1017/S0263593300006155

Nilsson, T. 1944. On the morphology of the lower jaw of Stegocephalia with special reference to Eotriassic steocephalians from Spitsbergen, II General part. Kungliga. Svenska VetenskapsAkademiens Handlingar Tredje serien, 21:1-69.

Pacheco, C.P.; Eltink, E.; Müller, R.T. \& Dias-da-Silva, S. 2016. A new Permian temnospondyl with Russian affinities from South America, the new Family Konzhukoviidae, and the phylogenetic status of Archegosauroidea. Journal of Systematic Palaeontology, 15:241-256. doi:10.1080/14772019.2016.11 64763

Pauliv, V.E.; Dias, E.V. \& Sedor, F.A. 2012. A new species of Sphenacanthid (Chondrichthyes, Elasmobranchii) from the Rio do Rasto Formation (Paraná basin), southern Brazil. Revista Brasileira de Paleontologia, 15:243-250. doi:10.4072/ rbp.2012.3.01

Pauliv, V.E.; Dias, E.V.; Sedor, F.R. \& Ribeiro, A.M. 2014. A new Xenacanthiformes shark (Chondrichthyes, Elasmobranchii) from the Late Paleozoic Rio do Rasto Formation (Paraná Basin), Southern Brazil. Anais da Academia Brasileira de Ciências, 86:135-145. doi:10.1590/0001-37652014107612

Pawley, K. 2006. The postcranial skeleton of temnospondyls (Tetrapoda: Temnospondyli). La Trobe University, Ph.D. thesis, $441 \mathrm{p}$.

Pawley, K. 2007. The postcranial skeleton of Trimerorhachis insignis (Temnospondyli: Trimerorhachidae): a plesiomorphic temnospondyl from the lower Permian of North America. Journal of Paleontology, 81:873-894. doi:10.1666/pleo05-131.1

Pawley, K. \& Warren, A.A. 2004. Immaturity vs. paedomorphism: a rhinesuchid stereospondyl postcranium from the Upper Permian of South Africa. Palaeontologia africana, 40:1-10.

Piñeiro, G.; Ramos, A. \& Marsicano, C. 2012. A rhinesuchid-like temnospondyl from the Permo-Triassico of Uruguay. Comptes Rendus Palevol, 11:65-78. doi:10.1016/j.crpv.2011.07.007

Price, L.I. 1948. Um anfibio labirintodonte da Formação Pedra de Fogo, Estado do Maranhão. Rio de Janeiro, Divisão de Geologia Mineralogia, Departamento Nacional de Produção Mineral, 32 p. (Boletim 124).

Ragonha, E.W. 1989. Placas dentárias de Dipnoi no Grupo PassaDois (P-Tr) da Bacias do Paraná. Apreciações ambientais, climáticas, cronológicas e estratigráficas. In: CONGRESSO BRASILEIRO DE PALEONTOLOGIA, 12, 1989. Anais, Curitiba, SBP, p. 195-206.
Ramos, B.D. \& Vega, C.S. 2011. Temnospondyl remains from the Late Permian Rio do Rasto Formation (Paraná Basin) of Brazil. Revista Brasileira de Paleontologia, 14:67-74. doi:10.4072/ rbp.2011.1.07

Richter, M. \& Langer, M.C. 1998. Fish remains from the Upper Permian Rio do Rasto Formation (Paraná Basin) of southern Brazil. Journal of African Earth Sciences, 27:158-159.

Ride, W.D.L.; Cogger, H.G.; Dupuis, C.; Kraus, O.; Mineli, A.; Thompson, F.C. \& Tubbs, P.K. 1999. International Code of Zoological Nomenclature. London, International Commission on Zoological Nomenclature, The Natural History Museum.

Rochinski, I.A. \& Dias, E.V. 2015. Análise de coprólitos e concreções da Formação Rio do Rasto (Permiano Superior) em Cândido de Abreu, Paraná, Brasil. In: ENCONTRO ANUAL DE INICIAÇÃO CIENTÍFICA, TECNOLÓGICA E INOVAÇÃO, 1, 2015. Available at https://www5.unioeste.br/eventos/ eaictiAnais/edicao-atual/ciencias-biologicas.html; accessed on 05/18/2020.

Rohn, R.; Babinski, M.E.C.B.O. \& Rosler, O. 1984. Glossopteris da Formação Rio do Rasto no sul do Estado do Paraná. In: CONGRESSO BRASILEIRO DE GEOLOGIA, 33, 1984. Anais, Rio de Janeiro, p.1047-1061.

Rohn, R. \& Roesler, O. 2000. Middle to Upper Permian Phytostratigraphy of the Eastern Paraná Basin. Revista da Universidade de Guarulhos-Geociências, 5:69-73.

Ruta, M.; Jeffrey, J.E. \& Coates, M.I. 2003. A supertree of early tetrapods. Proceedings of the Royal Society of London B, 270:2507-2516. doi:10.1098/rspb.2003.2524

Schneider, R.L.; Mühlmann, H.; Tommasi, E.; Medeiros, R.A.; Daemon, R.F. \& Nogueira, A.A. 1974. Revisão estratigráfica da Bacia do Paraná. In: CONGRESSO BRASILEIRO DE GEOLOGIA, 28, 1974. Anais, Porto Alegre, SBG, p. 41-65.

Schoch, R.R. 1999. Comparative osteology of Mastodonsaurus giganteus (Jaeger, 1828) from the Middle Triassic (Lettenkeuper: Longobardian) of Germany (Baden-Wurttemberg, Bayern, Thuringen). Stuttgarter Beiträge zur Naturkunde Serie B, 278:1-170.

Schoch, R.R. 2003. Early larval ontogeny of the PermoCarboniferous temnospondyl Sclerocephalus. Palaeontology, 46:1055-1072. doi:10.1111/1475-4983.00333

Schoch, R.R.; Fastnacht, M.; Fichter, J. \& Keller, T. 2007. Anatomy and relationships of the Triassic temnospondyl Sclerothorax. Acta Paleontologica Polonica, 52:117-136.

Schoch, R.R. \& Milner, A.R. 2000. Handbuch der paläoherpetologie (Encyclopedia of Paleoherpetology) Part 3B: Stereospondyli: stem-Stereospondyli, Rhinesuchidae, Rhytidostea, Trematosauroidea, Capitosauroidea. München, Verlag Dr. Friedrich Pfeil, $220 \mathrm{p}$.

Schultz, C.L.; Scherer, C.M.S. \& Barberena, M.C. 2000. Bioestratigraphy of Southern Brazilian Middle-Upper Triassic. Revista Brasileira de Geociências, 30:491-494.

Sedor, F.A. \& Costa, R. 2001. Associação Faunística do Membro Morro Pelado, Formação Rio Rasto (Permiano superior da Bacia do Paraná) na localidade de São Jerônimo da Serra, Paraná. In: CONGRESSO BRASILEIRO DE PALEONTOLOGIA, 17, 2001. Boletim de Resumos, Rio Branco, p. 179.

Silva, R.C.; Sedor, F.A. \& Fernandes, A.C.S. 2012. Fossil footprints from the Late Permian of Brazil: an example of hidden biodiversity. Journal of South American Earth Sciences, 38:31-43. doi:10.1016/j.jsames.2012.05.001

Sipp, G.S.; Schultz, C.L. \& Dias, E.V. 2018. O uso de tomografia computadorizada na identificação taxonômica de uma 
nova espécie de anfíbio do Permiano da Bacia do Paraná. In: REUNIÃO ANUAL REGIONAL DA SOCIEDADE BRASILEIRA DE PALEONTOLOGIA - PALEO-RS, 2018. São Leopoldo.

Souza, A.S. \& Vega, C.S. 2011. Short-snouted skull, mandible, axial and apendicular skeleton materials of Temnospondyli amphibians (Rio do Rasto Formation, Paraná Basin, Brazil). Ameghiniana, 48:R212.

Stollhofen, H.; Stanistreet, I.G.; Rohn, R.; Holzförster, F. \& Wanke, A. 2000. The Gai-As Lake System, Northern Namibia and Brazil. In: E.H. Gierlowski-Kordesch \& K.R. Kelts (eds.) Lake basins through space and time, Tulsa, AAPG, p. 87-108 (Studies in Geology 46). doi:10.1306/St46706C6

Strapasson, A.; Pinheiro, F.L. \& Soares, M.B. 2015. On a new stereospondylomorph temnospondyl from the Middle/Late Permian of Southern Brazil. Acta Palaeontologica Polonica, 60:843-855. doi:10.4202/app.00059.2014

Vega-Dias, C.; Dias, E.V. \& Richter, M. 2000. Actinopterygian remains from the Rio do Rasto Formation, Upper Permian of the Paraná Basin, Brazil. Acta Geologica Leopoldensia, 23:21-31.

Watson, D.M.S. 1919. The structure, evolution and origin of the Amphibia - The "Orders" Rachitomi and Stereospondyli.
Philosophical Transaction of the Royal Society of London B, 209:1-73. doi:10.1098/rstb.1920.0001

Watson, D.M.S. 1962. The evolution of the labyrinthodonts. Philosophical Transactions of the Royal Society of London B, 245:219-265. doi:10.1098/rstb.1962.0010

Witzmann, F. \& Schoch, R.R. 2006. The postcranium of Archegosaurus decheni, and a phylogenetic analysis of temnospondyl postcrania. Palaeontology, 49:1211-1235. doi:10.1111/j.1475-4983.2006.00593.x

Yates, A.M. \& Warren, A.A. 2000. The phylogeny of the 'higher' temnospondyls (Vertebrata: Choanata) and its implications for the monophyly and origins of the Stereospondyli. Zoological Journal of the Linnean Society, 128:77-121. doi:10.1006/ zjls.1998.0184

Zittel, K.A. 1887-1890. Handbuch der Paläeontologie. Abteilung 1. Palaozoologie Band III: Vertebrata (Pisces, Amphibia, Reptilia, Aves). Berlin, Oldenbourg, 890 p.

Received in 24 April, 2019; accepted in 30 March, 2020. 